\title{
An Estimate of the Pitting Strength of Steel Materials
}

A single expression for estimating the nominal pitting strength of steel materials, based on surface hardness, is developed from first principles for a reliability of $99 \%$ at $10^{7}$ load cycles. It requires the hardness values to be measured in Vicker's hardness scale. The expression may be used for any steel material processed by hot rolling, cold drawing, quenching and tempering or case-hardening. The formulation incorporates a nominal design factor at $99 \%$ reliability which is estimated from a probabilistic model based on the lognormal probability density function. Pitting strength estimates from the expression are compared with those of American Gear Manufacturers Association (AGMA) estimates and data from other sources as indicated in Tables 3 and 4. The expression predicts lower values at low hardness but higher values at high hardness. The variance is between $15.21 \%$ and $10.13 \%$ for through-hardened steels. For case-hardened steels, the variances range from $14.23 \%$ to $20.26 \%$ between the estimates and available data. These variances appear to be reasonable considering the many factors involved in pitting resistance. The main advantage of this study is that pitting strength of new steel materials may be estimated for initial design sizing without long and costly contact fatigue testing which of course is necessary for design validation. Also, the estimation method developed may be applied to other materials, metallic and non-metallic. Suggestions are made for estimating some pertinent pitting strength adjustment factors when considering field or service pitting strength.

Keywords: Hertz stresses, Pitting, Friction, Rolling-sliding, Fatigue, Reliability,

\section{INTRODUCTION}

Loads are transmitted from one component to the other at joints where contact exists between them. When there is a poor fit between bodies in contact, the contact is described as non-conformal; otherwise it is described as conformal when a good fit exists. Non-conformal contacts are common when two elastic bodies with curved surfaces are brought together. The bodies initially make a point or line contact but due to their elasticity, the point or line contact changes to an area contact because of the deformation caused by the load pressing the two bodies together. The contact area is very small compared to the sizes of the bodies; being typically three orders of magnitude smaller than that of conformal contact [1]. The three-dimensional nature of solids means a three-dimensional stress field is setup at the contact zone. Contact stress problems are encountered in localized contacts occurring in gears, brakes, clutches, rolling bearings, wheels, rails, screws and riveted joints. Other situations are cam and follower pairs like automotive valve cam and tappet pair [2].

Examples where sliding motion is combined with rol-

Received: September 2020, Accepted: November 2020

Correspondence to Prof. Edward E. Osakue

Department of Industrial Technology, Texas

Southern University, Houston, Texas, USA

Email: edward.osakue@tsu.edu ling motion with about $1 \%$ sliding includes ball and roller bearings, cam with roller follower; but nip-rolls, and cylindrical gear meshes have higher sliding speed. Screw gears, spiral bevel gears, hypoid gears, and wormsets have high relative sliding speed in their contact interfaces [2].

In frictionless non-conformal contact under a static normal load, a localized complex stress state that is concentrated in a small volume of material is produced. A maximum shear stress is generated at some depth below the surface. Relative rolling motion between contacting bodies creates the same type of stress field as in static normal load but the contact patch and hence the stress field is in continuous motion. The stresses are therefore, subject to cyclic variation and the contacting surfaces are loaded in fatigue. The presence of relative sliding motion combined with rolling motion and or external tangential load, introduces tractions from frictional resistance between the contacting surfaces. The stress field is then modified and stress component values are higher than when tractive forces are not present in the contact zone. Specifically, a tensile stress component is added to the stress field, thus promoting fatigue failure which is facilitated by the presence of tensile stresses.

Contact or surface fatigue results from repeated disturbance of the load pressing contacting surfaces together. Surface fatigue failure may be defined as the progressive loss of surface quality resulting from shearing and tearing away of particles that are distributed over an entire active surface usually due to combined rolling and sliding 
motions. Contact fatigue process can be divided into two main parts: (a) initiation of micro-cracks due to local accumulation of dislocations, high stresses in local points, plastic deformation around inhomogeneous inclusions or other imperfections on or under the contact surface; (b) crack propagation, which causes permanent damage to a mechanical element, that is, exceeding the fracture toughness of the material $[3,4]$. It should be noted that only tensile stress leads to crack growth [5]. The repeated rolling or rolling-sliding contact conditions cause permanent damage to the material due to accumulation of deformation [4]. If pressures are low to moderate, surface failure may not be noticeable until loose particles develop. The surfaces may even become polished, with machining and grinding marks disappearing. In dry contact, surface failure may consist of a flaking of oxides. In lubricated surfaces, it may occur due to direct contact of asperities when the lubricating film thickness is not sufficiently developed for complete separation of the contacting surfaces. Shearing and tearing off of large particles may be from only a portion of the contact surface due to misalignment and unanticipated deflections which often happens when gears are mounted on insufficiently rigid shafts, especially when the gears are overhung. Rapid deterioration of contact surfaces may occur from insufficient lubrication, or from negligence in lubrication and protection from dirt [6]. Contact fatigue is extremely important for all engineering applications involving localized contacts such as in gears, brakes, clutches, ball bearings, rolling bearings, wheels and rails, cams and followers, chain hooks and chains, screws and riveted joints [7].

Contact fatigue damage can result from surface generated cracks and or subsurface generated cracks. Crack formation is initiated when shear stresses are high enough to produce plastic strains that lead to the formation of microcracks or magnification of existing microcracks. Crack formation is enhanced by the presence of tensile stresses in the contact patch when repeatedly loaded. Surface inclusion sites create local stress concentrations which increase chances of surfaceinitiated cracks [6]. Similarly, surface defects such as dents, scratches, machining and grinding marks all contribute to higher incidence of surface originating contact fatigue failure [8]. In properly lubricated spur gears during normal or steady-state operation, an oil film exists. During normal operation in gears carrying extremely high specific load, the oil film may be squeezed out of the mesh or it may become difficult sustaining the oil film because of the heat generated and lubricant breakdown can occur. Consequently, metallic contact between the gear teeth is inevitable and frictional load sets in. During transient-state operation such as startup or shutdown, boundary lubrication is most likely and frictional load is inevitable. In greaselubricated gears, an oil film is not formed and boundary lubrication predominates, so some metallic contact between the gear teeth generally occurs, resulting in higher frictional load and tensile stresses. The higher the tangential stress, the more likely will be surface generated contact fatigue. Surface originating cracks are more prevalent than subsurface generated cracks [8].

Subsurface cracks can originate from the maximum shear stress that is created at a subsurface layer in the contact zone because it can lead to plastic deformation capable of initiating microcracks. In pure rolling, the subsurface shear stress produces intense plastic strain which accumulates as the same volume is stressed with each load cycle until a crack is initiated. The crack can propagate to the surface and a pit is formed when the stressed volume is detached. The presence of subsurface inclusions, phase and grain boundary discontinuities and pile-up of dislocations at phase and grain boundaries [9], greatly increase the chances of the formation of subsurface cracks.

Pitting strength is the contact stress capability of a surface loaded repeatedly in rolling or rolling-sliding motion. Below this stress capability, failure by pitting is prevented. The pitting damage occurrence is strongly influenced by the tribological system consisting of the contacting surfaces and the lubricant. The lubricant's base oil properties and additive substances, as well as the surface roughness are the main parameters commonly considered for an improvement of the pitting load-carrying capacity of components. Nevertheless, the material strength plays a major role also in determining the pitting load-carrying capacity of components. For instance, increases as large as three times load capacity can be achieved using different gear materials. For this reason, the pitting strength is an important parameter to be taken into account in the selection of new gear materials [10]. There is common agreement that contact strength is influenced by Hertz stresses, load cycles, hardness, surface roughness, temperature, and degree of lubrication [11].

Contact fatigue related failures happen after many load cycles, for example, pitting usually occurs after more than 10,000 load cycles and there is no endurance limit in surface fatigue [12]. Surface treatments such as carburizing or nitriding give hard surface layers that can produce good fatigue and wear resistance [13]. Gears are perhaps the most common machine components where contact stresses have been and are still an area of intense study. American Gear Manufacturers Association (AGMA) gear pitting and bending fatigue strength data are based on tests on actual gear teeth and is determined at $99 \%$ reliability and $10^{7}$ load cycles $[11,12]$ and at a temperature of $120^{\circ} \mathrm{C}$ and below [14]. The strengths are called nominal strength because they are modified for service or field applications using adjustment factors.

Presently, the pitting strength of gears, cams, etc. made of steel and indeed of other materials is determined experimentally. This is generally an expensive and time-consuming endeavor because it involves testing samples to failure. Very high load cycle strengths are very expensive to obtain because of the long hours involved in running tests on several specimens [15]. The use of new materials in design is of special consideration because pitting strength experiments may have to be conducted before they can be used for initial design. New materials are appearing all the time and innovation in design is frequently made possible by the use of new materials [13]. If the pitting strength of materials can be estimated from some more easily determined properties like yield strength or tensile strength, initial design may be done, and capacity performance testing can be carried out latter. This will eliminate initial experimentations for pitting strength determi- 
nation, speed up product development, and reduce product cost.

The objective of this study is the formulation of a theoretical approach for the estimation of the nominal pitting resistance capacity of steel materials at $99 \%$ reliability. The stress state is compressive in contact engagement, so failure should be associated with compressive yield strength and compressive elastic modulus for Hertz contact stresses because the Hertz contact stress theory assumes elastic conditions for the contacting bodies. The compressive yield strength and tensile yield strength for most ductile materials are approximately the same, but are not for brittle materials. The compressive elastic modulus and tensile elastic modulus for ductile or brittle materials are approximately the same. Presently, correlations of hardness to pitting strength of steel materials are empirical $[11,14]$. This means experiments have to be carried out first before reasonable estimate of contact strengths can be made. Therefore, it will be helpful to have a scientifically based theoretical method of estimating pitting strength.

\section{HERTZ CONTACT MODEL}

Hertz contact stress bears the name of the German physicist, Henry Hertz who first developed expressions for the stresses created when curved frictionless surfaces are loaded in contact in 1881[16]. Therefore, contact stresses are commonly called Hertz contact stresses and they are computed by means of the theory of Hertz which provides mathematical expressions for the stresses and deformations of curved bodies in contact. The following are the assumptions in the solution of Hertz elastic contact problems $[1,17]$ :

1. The surfaces of the contacting bodies are smooth.

2. The load is normal to the plane of contact.

3. The materials of the contacting bodies are homogeneous and isotropic.

4. The size of the contact patch is small compared to the size of the surfaces of the contacting bodies.

5. Deformations in the contact zone are elastic and obey Hooke's law.

6. The contacting bodies are at rest.

7. There is no tangential force on the contact plane.

The general contact case involves two solid bodies with different radii of curvature in a pair of principal planes with $\mathrm{x}$-axis (minor axis) and y-axis (major axis) passing through the contact point at no load. The contact patch for this situation is elliptical in shape with major and minor diameters. It is usually assumed that convex surfaces have positive radius of curvature and concave surfaces have negative radius of curvature. The presence of roughness on the contacting bodies slightly influences the pressure distribution and the contact patch. When the effective surface roughness is less than $5 \%$ of the maximum normal deformation, Hertz theory for smooth surfaces can be used. The effective surface roughness is defined as the square root of the sum of the squares of the two surface roughness values. Also, Hertz presupposes that the maximum normal approach or deformation be limited to $10 \%$ of the minimum radius of curvature of the two bodies, although good agreement with theory is reported for $30 \%$ in some experiments [18, 19]. Two special cases of practical importance to the design engineer are the contact of two spheres and the contact of two cylinders [11].

\subsection{Contact Stresses in Frictionless Spherical Contact}

The contact of two spheres is depicted in Fig. 1a with the radii and the principal directions indicated. The principal planes are defined by $y-z$ and $x-z$ planes. Fig. $1 \mathrm{~b}$ shows the stress distribution over the contact patch along the principal directions. The concentrated normal force acts along the $\mathrm{z}$-axis pressing the bodies together.

With reference to Norton [2] and Mott [14] and after performing some mathematical simplifications, the expression for the maximum contact pressure may be rendered as in Eq. (1a) and the half-size of the contact patch may be expressed as in Eq. (1b):

$$
\sigma_{H}=-\frac{100}{\pi} \times\left[6 K_{s} F_{c}\left(\frac{E_{c}}{\rho}\right)^{2}\right]^{1 / 3} \quad a=\frac{3 K_{s} F_{c} \rho}{4 E_{c}}
$$

Please refer to Nomenclature for the definition of variables and parameters.

Equation (1) has two entries and should be interpreted as Eq. (1a) and Eq. (1b) from left to right. The same rule should be applied to other equations of similar nature.

In Eq. (1a):

$$
E_{c}=\frac{2 E_{1} E_{2}}{E_{1}\left(1-v_{2}^{2}\right)+E_{2}\left(1-v_{1}^{2}\right)} \rho=\frac{2 r_{1} r_{2}}{r_{2} \pm r_{1}}
$$

The stress components as a function of distance inside the contacting bodies in the z-direction are expressed in $\mathrm{Eq}(3)[2,20]$ :

$$
\begin{aligned}
& \sigma_{z}=\sigma_{H}\left[1+\frac{z^{2}}{a^{2}}\right]^{-1} \\
& \sigma_{x}=\sigma_{y}=\sigma_{H}\left\{(1+v)\left(1-\left|\frac{z}{a}\right|\right) a \tan \left|\frac{a}{z}\right|-0.5\left[1+\frac{z^{2}}{a^{2}}\right]^{-1}\right\}
\end{aligned}
$$
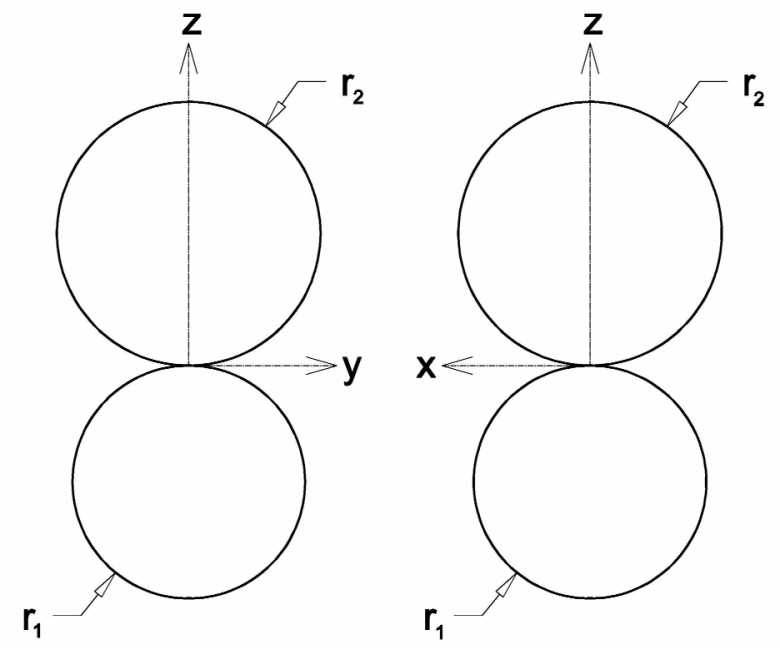

a) Two spheres in contact 


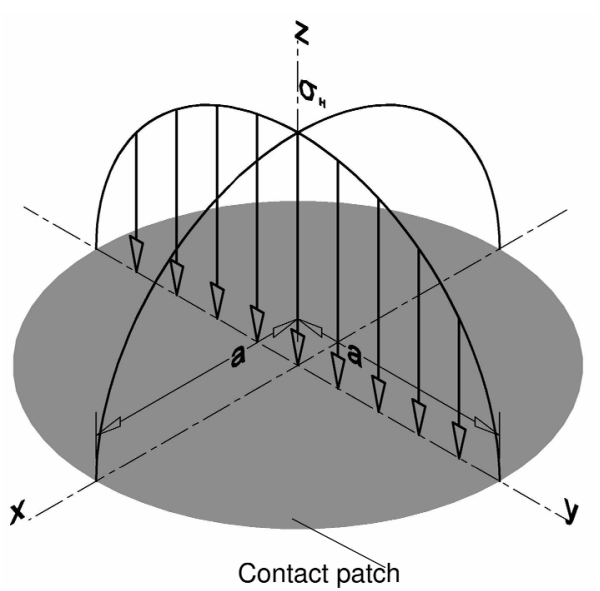

b) Contact pressure distribution

\section{Fig. 1: Spherical contact}

The coordinate $\mathrm{z}$ is positive for the upper body and negative for the lower body. Because there are no shear stresses present, theses normal stresses are also principal stresses.

At the surface where the concentrated load acts:

$$
\begin{aligned}
& z=0 \\
& \sigma_{z}=\sigma_{H} \quad \sigma_{x}=\sigma_{y}=0.5 \sigma_{H}(1+2 v)
\end{aligned}
$$

\subsection{Contact Stresses in Frictionless Cylindrical Contact}

The contact of two cylinders is depicted in Fig. 2a with the radii and the principal directions are shown. The radius of each cylinder is shown in the $y-z$ principal plane. In the $\mathrm{x}-\mathrm{z}$ principal plane, the radius of each cylinder is infinite. Fig. 2b shows the stress distribution over the contact patch along the principal directions. The concentrated normal force acts along the z-axis pressing the bodies together.

With reference to Norton [2] and [14] and after performing some mathematical simplifications, the expression for the maximum contact pressure may be rendered as:

$$
\sigma_{H}=-\left[\frac{K_{s} F_{c}}{\pi b_{e}} \cdot \frac{E_{c} \times 10^{3}}{\rho}\right]^{1 / 2} \quad a=\frac{2 K_{s} F_{c}}{\pi b_{e} \sigma_{H}}
$$

where:

$$
\rho=\frac{2 r_{1} r_{2}}{r_{2} \pm r_{1}} \quad b_{e}=\lambda_{e} b
$$

The stress components as a function of distance in the z-direction are given in Eq. (7) [2, 20]:

$$
\begin{aligned}
& \sigma_{z}=\sigma_{H}\left[\sqrt{1+\frac{z^{2}}{a^{2}}}\right]^{-1} \\
& \sigma_{y}=\sigma_{H}\left\{\left(1+\frac{z^{2}}{a^{2}}\right)^{0.5}\left(2-\left[1+\frac{z^{2}}{a^{2}}\right]^{-1}\right)-2\left|\frac{z}{a}\right|\right\} \\
& \sigma_{x}=2 v \sigma_{H}\left\{\left(1+\frac{z^{2}}{a^{2}}\right)^{0.5}-\left|\frac{z}{a}\right|\right\}
\end{aligned}
$$

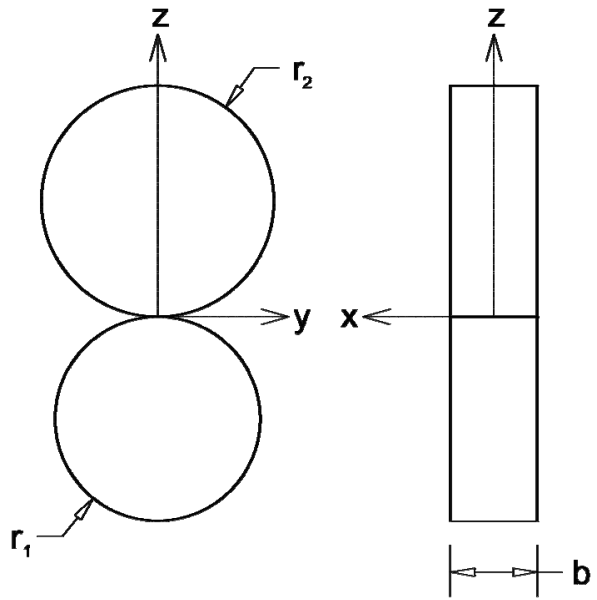

a) Two cylinders in contact

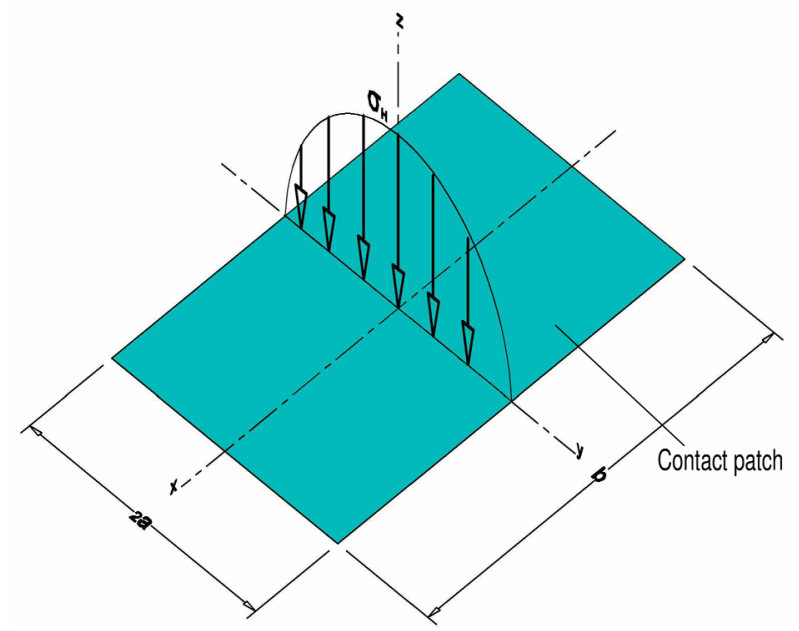

b) Contact pressure distribution

\section{Fig. 2: Cylindrical contact}

Like the situation in spherical contact, because there are no shear stresses present, theses normal stresses are also principal stresses.

At the surface, $z=0$

$$
\sigma_{y}=\sigma_{z}=\sigma_{H} \quad \sigma_{x}=2 v \sigma_{H}
$$

\section{TYPES OF CONTACT FAILURE}

The failures associated with non-conforming contacts are closely related to the maximum contact pressure calculated by the Hertz theory [6]. Common failure modes associated with contact stresses are brinelling, pitting, scoring, and spalling.

\subsection{Brinelling}

When curved bodies are in static contact, failure takes the form of brinelling in which a dent is created when the applied load exceeds the contact yield strength, often called indentation pressure. When the load is static and large enough, yield occurs initially at a subsurface location and the region of plasticity is initially contained by an elastic region. If the load is increased further, then the plastic region grows. The state of 'full plasticity' is defined when the plastic region reaches the surface. For metals, the contact yield strength is then approximately 
1.6 times the tensile yield strength for spherical contact 1.67 times the tensile yield strength for cylindrical contact [21].

\subsection{Pitting}

Pitting is the formation of tiny pits on surfaces of objects in rolling, or rolling-sliding motion in the presence of high contact stress. The process is believed to be associated with small surface initial cracks which grow under repeated contact loading. Eventually, the cracks become large enough for unstable growth to occur and some surface layer materials break away, resulting in surface pits [4]. In spherical and elliptical contacts, a small tensile stress exits at the edges of the contact patch. A rectangular contact patch has a geometric stress concentration at the edges of contact where the material is weaker for lack of side support. Surface cracks formation is facilitated by machining and grinding marks and surface flaws such as dents and scratches which when combined with geometric stress concentrations, greatly increases the possibility of surface cracks formation. In fact, surface-originating pits are more prevalent than subsurface-generated cracks [22]. Once a pit is formed, the site acts as a local stress concentration point which promotes formation of more cracks and pits. In addition to contact stress, pitting is influenced by sliding velocity, lubricant viscosity, and friction [23]. In the case of an oil film being present between contacting surfaces, the shear forces in the oil due to its viscosity are transferred to the surfaces of the contacting bodies, because the oils are incompressible.

In Hertzian contact problems, pure rolling occurs when the relative velocity between contacting bodies is zero. During pure rolling, surface initiated pitting progress only in the presence of oil which fills the crack, acting as a hydraulic wedge. Experiments indicate that only cracks with their lips facing the approaching load would progress to failure. Pitting may be caused by the intrusion of lubricating oil into surface cracks which creates fluid pressure wedge for the cracks to develop into pits [9]. Fatigue pits caused by pure rolling occur without plastic deformation of the surface. The resulting pits are small and seldom give more than a "frosted" appearance to the surface. More often in Hertzian contact problems, rolling is associated with some sliding and tractive forces are brought into play at the contact interface. In rolling-sliding situation, rolling and sliding may occur in the same direction or in opposite directions. The former case is called positive sliding while the latter case is called negative sliding. Pitting damage is more severe in negative sliding cases [24]. Studies indicate that surface tractions in a Hertzian contact lead to a tensile stress component in the stress field which increases the maximum contact and shear stresses and causes the maximum shear stress to move closer to the contact surface [2]. Hence the possibility of surface or pitting crack initiation arising from Hertz contact stress increases due to the tensile stress on one hand, and due to the location of a crack in the subsurface, moving closer to the surface on the other hand. The presence of a lubricant in the contact interface reduces the frictional tractions compared to metal-to-metal contact.
Once surface pitting has been initiated, the surface gets roughened as tiny pieces of material from the contacting surfaces are released and the operation of the contacting bodies becomes noisy. If allowed to continue, fracture of the components will follow and catastrophic failure may occur. Pitting failure therefore manifests as wear on the contacting surfaces and is usually a gradual form of failure [25]. It has become a major concern in certain classes of industrial gear applications, such as wind turbine gearboxes, as a consequence of the increasing utilization of surface hardened gears (case carburized, nitrided, etc.), of steels of improved quality and high cleanliness, and of lubricants with sophisticated additives that enable gears to work in non-favorable lubrication conditions without the occurrence of other types of damages [9]. Pitting resistance is enhanced by large number of gears teeth, positive profile shift in gears with small number of teeth, higher pressure angle, higher surface hardness, and more viscous lubricant.

The distortion energy theory may be used to assess pitting failure when the materials in contact are ductile. Therefore, the equivalent surface contact stress at the surface and is obtained as [26]:

$$
\sigma_{e q}=\sqrt{\frac{1}{2}\left[\left(\sigma_{x}-\sigma_{z}\right)^{2}+\left(\sigma_{y}-\sigma_{z}\right)^{2}+\left(\sigma_{z}-\sigma_{x}\right)^{2}\right]}
$$

In spherical contact based on Eq. (4), the equivalent surface contact stress is given Eq. (10a) in general and by Eq. (10b) when $v=0.3$.

$$
\sigma_{e q}=\sigma_{H}[1-0.5(1+2 v)] \quad \sigma_{e q}=0.2 \sigma_{H}
$$

In cylindrical contact based on Eq. (8), the equivalent surface contact stress is given Eq. (11a) in general and by Eq. ( $11 \mathrm{~b}$ when $v=0.3$.

$$
\sigma_{e q}=\sigma_{H}\left[\sqrt{1-2 v+2 v^{2}}\right] \quad \sigma_{e q}=0.2 \sigma_{H}
$$

\subsection{Spalling}

Spalling is also called galling and it is the formation of large and deep pits from subsurface cracking, but could occur as pitting from rolling-sliding deteriorates. It is therefore, a more severe surface damage than pitting and is commonly associated with subsurface cracks that may be initiated from high shear stresses. Depending on the microstructure and grain orientation of the material, internal stress concentrations are formed that can lead to crack initiation which is facilitated by inclusions, especially those that are hard, brittle and irregular in shape [24]. Below the contact surface, a maximum shear stress is developed that causes differing elastic and plastic deformation that can initiate a crack. The shear stress-initiated crack beneath the surface is due to excessive repeated Hertz contact stresses. It gradually develops to the surface, resulting in the shearing away of some materials thus leaving a pit behind. With tractive forces in the contact zone, the maximum shear stress becomes higher and its location closer to the surface, thus increasing the chances of spalling. Sub- 
surface initiated cracks are generally more irregular than surface-initiated ones. As the subsurface cracks develop and grow to the contact surface, a surface layer loosens and eventually breaks away, leaving a relatively large pit. The subsurface initiated damages have steep exit walls, often inclined at more than $45^{\circ}$ to the contact surface on all sides [27]. Spalling can also develop from fatigue cracks initiated at the metallurgical notch formed between case and core hardness in case-hardened materials. The case-core hardness interface is relatively deep so that the size and depth of the resulting pits may be significantly larger than those of maximum subsurface shear stress. The pits act as stress concentrations which may cause other modes of failure, while the debris from the pits can cause abrasive wear and contaminate lubricants. The loose debris batters the fractured surface, obliterating the surface features [8]. Spalling occurs more often in rolling element bearing races [6].

For the frictionless contact of spheres, the normal stresses of Eq. (3) are also principal stresses and the maximum shear stress is:

$$
\begin{aligned}
& \tau_{H}=\left|\sigma_{x}-\sigma_{z}\right|= \\
& =-0.5 \sigma_{H}\left[0.5(1-2 v)+\frac{2}{9}(1+v) \sqrt{2(1+v)}\right]
\end{aligned}
$$

For $v=0.3$, the maximum shear stress is given by Eq. (13a) and it occurs at a depth given by Eq. (13b).

$$
\tau_{H}=-0.333 \sigma_{H} \quad z_{H}=0.6374 a
$$

The equivalent contact stress for the spherical contact subsurface failure based on the distortion energy theory is:

$$
\sigma_{e q}=\sqrt{3} \tau_{H}=-0.5774 \sigma_{H}
$$

For the frictionless contact of cylinders, the normal stresses of Eq. (7) are also principal stresses and the maximum shear stress is given by Eq. (15a) and occurs at a depth given by Eq. (15b).

$$
\begin{aligned}
& \tau_{H}=\max \left\{\left|\sigma_{x}-\sigma_{y}\right|,\left|\sigma_{y}-\sigma_{z}\right|,\left|\sigma_{x}-\sigma_{z}\right|\right\}=-0.304 \sigma_{H} \\
& z_{H}=0.786 a
\end{aligned}
$$

The equivalent contact stress for cylindrical contact subsurface failure based on the distortion energy theory is:

$$
\sigma_{e q}=\sqrt{3} \tau_{H}=-0.5265 \sigma_{H}
$$

\subsection{Scoring}

The term scoring is used interchangeably with scuffing and it is a more severe form of pitting where the surface damage is more pronounced revealing evidence of plastic deformation. However, it is not necessarily due to fatigue load but can occur when the contact stress is high enough to produce plastic deformation which results in tears and scratches on the rubbing surfaces. Failure by scoring appears in the form of coarse ridges from the tip down the contact surfaces to the pitch circle diameter in gears [28]. Scoring can happen very quickly, especially when a short overload occurs during operation. It is a common failure during the run-in phase of operations when contacting surfaces have not yet developed good smoothness. Scoring leads to increases in operating temperature, contact forces, and noise which facilitate fracture of teeth in gears. It is enhanced by lubricant film breakdown which allows metal-tometal contact during motion. The lubricant film breaks down from overheating and the alternate welding and shearing of contacting surfaces result in metal particles being rapidly released from the surfaces [29]. For scoring failure, welding can follow yielding due to high contact stress and the heat that is generated from high frictional resistance due to metal-to-metal contact. The relative motion between the contacting surfaces facilitates the shearing of welded patches which makes the surfaces rougher. Scoring is aggravated by high contact stress and temperature because they make welding easier since material yield strength decreases with increasing temperature. Hence, minimizing the mesh contact stress and temperature is important in reducing the risk of scoring failure. Scoring failure is common in worm gears, screw gear, and hypoid gears where the relative sliding velocity of the contact surfaces is high [25]. Scoring can be minimized by using smaller gear modules, careful run-in, using extreme pressure (E.P.) oils, and using tip relief in gears which reduces sliding velocity during contact.

Surfaces of scoring failure have a rough or matte texture under magnification and appear to be torn and plastically deformed [30]. According to Ishibashi et al. [31] surface cracks can only propagate if the mean Hertzian stress is high enough. Plastic deformation can occur only when a ductile material yields, therefore, we may associate scoring failure with the yielding of contacting surfaces. Consequently, it may be assumed that surface contact failure occurs in scoring when the mean Hertzian stress is equal to or exceeds the contact yield strength.

For spheres in contact, the mean contact pressure is [2]:

$$
p_{H}=\frac{2}{3} \sigma_{H}=0.6667 \sigma_{H}
$$

For cylinders in contact, the mean contact pressure is [2]:

$$
p_{H}=\frac{\pi}{4} \sigma_{H}=\frac{3.1416}{4} \sigma_{H}=0.7854 \sigma_{H}
$$

Osakue and Anetor [32] have developed an expression for the scoring strength of bronze materials in worm gear drives based on Eq, (18).

Table 1: Summary of Contact Failure Types

\begin{tabular}{|l|l|c|}
\hline \multirow{2}{*}{ Contact Type } & Failure Type & $\begin{array}{c}\text { Equivalent } \\
\text { Contact Stress } \\
\text { (MPa) }\end{array}$ \\
\hline \multirow{3}{*}{ Spherical } & Pitting & $0.2000 \sigma_{H}$ \\
\cline { 2 - 3 } & Galling & $0.5774 \sigma_{H}$ \\
\cline { 2 - 3 } & Scoring & $0.6667 \sigma_{H}$ \\
\hline \multirow{3}{*}{ Cylindrical } & Pitting & $0.7616 \sigma_{H}$ \\
\cline { 2 - 3 } & Galling & $0.5265 \sigma_{H}$ \\
\cline { 2 - 3 } & Scoring & $0.7854 \sigma_{H}$ \\
\hline
\end{tabular}


Table 1 summaries the failure modes for Hertzian contact subjected to dynamic load from the above discussions. Brinelling is caused by static load which produces a dent on a surface and does not apply in dynamic situations. Pitting and spalling are induced by repeated dynamic loads, while scoring is caused by dynamic overload associated with sliding or rollingsliding motions. Pitting and scoring are surface initiated but pitting is fatigue induced failure while scoring is not necessarily fatigue related. Scoring is a severe form of pitting and objects in spherical or cylindrical can easily fail by it as it yields the highest equivalent surface stress in each case as may be observed in Table 1. Objects in spherical contact are more prone to galling failure than those in cylindrical contact while objects in cylindrical contact are more prone to pitting failure than those in spherical contacts

\subsection{Influence of Friction in Contact Problems}

Friction is a force that resists the relative motion between two or more objects and is caused by molecular adhesion, surface roughness, and deformations. The presence of friction greatly complicates contact problems and only a qualitative summary is attempted here. Later, an approach taking account of friction through a pitting strength sliding factor based on experimental data is presented. For now, it should be noted that the solutions provided by Hertz theory apply to frictionless contact. However, friction is unavoidable in practical contact situations such as gear meshes, wheels and rails, etc. A tangential force in a contact problem introduces a slip motion at the edge of a contact patch no matter how small in value because an infinite tangential stress is created there [33].

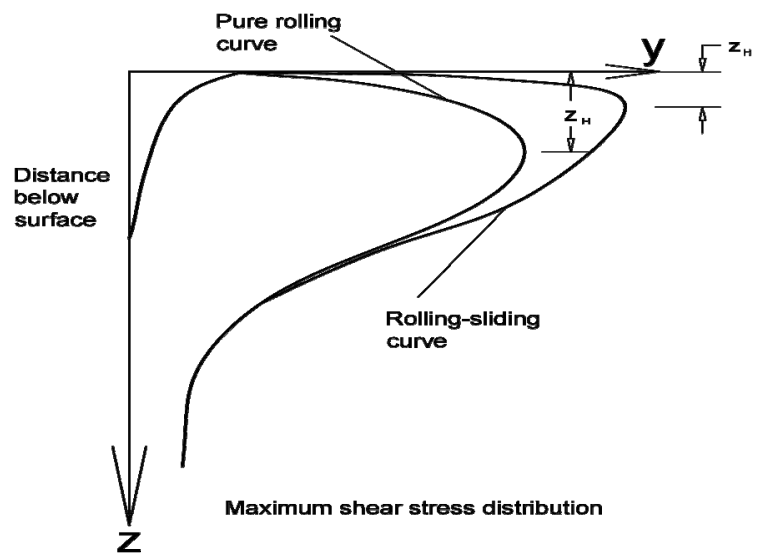

Fig. 3: Maximum shear stress distributions in contact

Fig. 3 is adapted from [24] and shows the shear stress distribution below the contact patch in pure rolling and rolling-sliding motions for the lower object in a contact. For instance, the presence of frictional force in cylindrical contact introduces a tensile stress component on the trailing edge in the contact patch at the surface, increases the normal contact stress component, increases the shear stress components, and causes the upward migration of the maximum shear stress. At low values of friction coefficient $(<0.1)$, the maximum shear stress occurs below the surface. When the coefficient of friction is about 0.3 and above, the maximum shear stress will occur at the surface. As the friction coefficient increases, both the maximum contact stress and maximum shear stress increase. For example, when the coefficient of friction is 0.33 ; the maximum contact stress value increases by about $38 \%$ above the value at pure rolling for line contact and the ratio of the maximum shear stress to the maximum contact stress increases to about 0.40. Also, the maximum tensile stress grows to a value of 0.66 times the maximum contact stress at pure rolling [2]. Fatigue crack initiation and propagation are facilitated by tensile forces. Therefore, friction in the contact patch increases the possibility of early failures by pitting and perhaps scoring. Fatigue fractures arise at the contacting surfaces due to the action of frictional forces [17].

\subsection{Stress Concentrations in Contact Problems}

Stress concentration occurs at or near a discontinuity or stress raiser in a material and gives rise to unusually high stresses near the stress raiser while much lower stress values exist on the remainder of the cross-section. Common discontinuities include holes, fillets, notches and scratches, inclusions, grain boundaries, and phasechange boundaries. Stress concentration can also be caused by sudden changes in material properties such as elastic modulus, linear expansivity, and thermal conductivity in composite materials. Practically, some factors tend to limit stress concentration effects, and these include local plastic deformation, compressive residual stresses, notch radius, component size, and load type. When local plastic deformation occurs near stress raiser, the stress concentration is reduced in magnitude and if a design accommodates plastic deformation, it may be reasonable to ignore stress concentration or incorporate it in a safety or design factor [1].

Two types of stress concentrations ought to be considered in contact problems. These are surface stress concentration and subsurface stress concentration, noting that surface or subsurface inclusions serve to magnify their values. Machining and grinding operations are known to leave fine surface cracks that are sites of stress concentrations which can propagate to create pits and polishing inhibits pitting probably by the removal of these cracks. Also, local asperity contacts will introduce stress concentrations [34] at the surfaces of contact. Now, there is geometric stress concentration at the ends of a rectangular contact area where the material is weaker without side support [6]. At the subsurface, grain boundary discontinuities; phase change interfaces, and inclusions are potential stress raisers. It is therefore, obvious that stress concentration effects ought to be considered in contact stress analysis, especially when surfaces are hard and rough. However, in contact problems, stress concentration factors and notch sensitivity are poorly defined and definitive values appear lacking currently.

Kastratovic et al. [35] developed an approximate numerical method for estimating a normalized stress intensity factor (SIF) of three co-planar cracks in mode I fracture state in a solid. The SIF is the basic parameter used in fracture mechanics for stress field determination in the tip region of a crack. The accuracy of the method 
was verified by comparing its predictions with finite element method (FEM) solutions. This method appears to hold promise in quantifying surface stress raisers in contact stress problems involving machined surfaces which often have multiple scratches. Grbovic et al. [36] simulated a single surface crack initiation and propagation to fracture of a dental implant. It gives a good understanding of crack formation and growth to failure of a component. The failure mode simulated is typical of components like shafts but the method may be modified for applications for contact problems. Petrasinovic el al. [37] experimentally fatigue tested a full-scale aircraft wind made from 2024-T3 aluminum to failure. Results of the test were found to be in very good agreement with estimates from advanced numerical methods. The study may help in the use of advanced numerical methods in simulating failure due to contact stresses.

\section{DYNAMIC CONTACT YIELD AND THEORETICAL CONTACT STRENGTH}

The tensile yield strength is the stress at which plastic or non-recoverable deformation is initiated when a material is loaded in tension. Most ductile materials tend to have equal tensile yield and compressive yield strengths, as well as equal ultimate tensile and compressive or crushing strengths with the ultimate shear strength lower than the ultimate tensile strength. They are weakest in shear, so failure occurs along shear planes at $45^{\circ}$ to the tensile stress direction when under tension [2]. Brittle materials generally have ultimate tensile strength lower than the ultimate compressive strength and the shear strength is in between the ultimate tensile and ultimate compressive strength values. They are weakest in tension and failure occurs along planes of maximum principal normal stress under tensile stresses. The failure plane is at right angle to tensile stress direction [2].

Objects in Hertzian contact such as gears, cams and followers, etc., are often associated with vibrational impact due to local acceleration and deceleration during meshing. Therefore, yielding of their surfaces should be related to the dynamic contact yield strength which tends to be higher than the static yield strength due to higher strain rate [38]. The dynamic contact yield strength may be defined for a body in contact with respect to the dynamic tensile yield strength [39]. For low-velocity impact, the dynamic yield strength is approximately equal to the static yield strength and the dynamic contact yield strength of ductile materials may be obtained as given in Eq. (19) [40].

$$
S_{y c}^{*}=(1.28+1.15 v) S_{y c}
$$

It may be assumed that pitting failure in a cylindrical contact occurs when the equivalent surface contact stress (Table 1) is at most equal to the dynamic contact yield strength as expressed in Eq. (20a).

$$
\sigma_{e q}=0.7616 \sigma_{H} \leq S_{y c}^{*} \quad \sigma_{e q} \approx \sigma_{H} \leq S_{c}^{*}
$$

In Eq. (20b), it is assumed that due to possible surface stress concentration factor, the equivalent contact stress at the surface is approximately equal to the maximum contact stress. This is more conservative than Eq. (20a) and is assumed based on the consideration of possible surface stress concentration for which there is presently no definitive guidance. For instance, a surface stress concentration factor of 1.313 (not unreasonable) in cylindrical contact raises the equivalent contact stress to the value of the maximum compressive stress. A slightly lower value is required for scoring failure to occur in cylindrical contact. Also, frictional influences are not exactly known, hence a conservative approach is reasonable in the current circumstances. Conservatism is a common approach in engineering analysis when exact and or experimental data are lacking. Finally, the assumption of Eq. (20b) provides built-in safety for steel materials, especially when material hardness is high and brittleness becomes a concern. The contact strength of the surface patch is distinguished from the compressive dynamic yield strength of the materials in contact in Eq. (20b).

From Eq. (20b) and Eq. (19):

$S_{c}^{*} \geq S_{y c}^{*}=(1.282+1.15 v) S_{y c} \quad S_{c}^{*} \geq(1.282+1.15 v) S_{y t}$

The inequality used in Eq. (21a) is due to the recognition of the fact that strain effect in dynamic contact is neglected and surface stress concentration is presumed without specific value assigned. Eq. (21b) applies to ductile materials when the tensile yield strength and the compressive yield strength are approximately the same. In contact problems, the state of stress is close to hydrostatic [8] which tends to increase the ductility of materials under tensile, compressive, and torsional tests. The increase has been observed not only with ductile metals but also with brittle metals and nonmetallic materials. Various brittle materials such as cast iron can deform plastically when subjected to hydrostatic pressure. The level of pressure to impact or enhanced ductility depends on the particular material [38]. Therefore, Eq. (21) should be applicable to brittle materials also, though in a more approximate sense.

\section{NOMINAL PITTING STRENGTH ESTIMATE}

The theoretical contact strength of Eq. (21) needs some modifications for practical applications. For instance, it does not account for the influence of friction which is important in real problems. Also, most strength data of materials such as yield strength, tensile strength and hardness are provided at minimum value which is unacceptable for use when failure is considered statistically [41]. Failure in contact is very close to a plane strain constrained phenomenon and should be considered too. From a reliability-based perspective, design parameters should have average or mean values and $50 \%$ reliability can be assumed for capacity models they are used in. However, higher reliability levels are usually required in practical situations. For example, AGMA gear pitting strength is assessed at $99 \%$ reliability and it is adopted as a reference in this study. Consequently, the nominal contact strength at $99 \%$ reliability for rolling-sliding motion may be expressed as:

$$
S_{c}^{\prime}=\frac{k_{s} k_{p} k_{o} S_{c}^{*}}{n_{o}}
$$




\subsection{Contact Strength Sliding Factor}

Practically, the presence of friction due to relative sliding motion in the contact zone weakens the contact strength of the material, resulting in the lowering of the theoretical contact strength. For instance, Ishibashi et al. [31] observed a $20 \%$ drop in bronze contact strength when sliding was introduced into the contact zone. Also, it may be inferred from Dudley [11] that the "running" contact strength for hardened steel or cast iron worm and phosphor bronze gear is about $50 \%$ of the "static" contact strength. Similarly, the running contact strength of cast iron worm and cast iron gear is about $47.2 \%$ of the static contact strength. Based on these meager data, the contact strength of bronze with sliding present is about $80 \%$ that when there is no sliding and the relative strength reduction of cast iron with respect to bronze is $47.2 / 50$ or 0.944 . We may therefore estimate contact strength sliding factor for cast iron as:

$$
k_{s}=0.8 \times 0.944=0.755
$$

The frictional properties of steel materials are very close to those of cast iron materials when lubricated, especially hard steels, though the latter generally shows slightly lower friction coefficient values when compared to mild or soft steels [26, 42]. Therefore, the sliding factor above will be assumed applicable to steel also.

\subsection{Plane Strain Factor}

Plane strain is a two-dimensional state of strain in which all the shape changes of a material happen on a single plane. Plane strain is applicable when an object is loaded and constrained in one principal direction, it will exist approximately in thick structures without end walls or very long members with thin cross-section. In the later example, material towards the center is constrained by the mass of material on either side and will be in a state of plane strain, approximately. In contact stress problems the loaded contact zone is very small compared to the size of the members and is surrounded by a body of material that is elastic and largely un-deformed, a situation that is close to plane strain condition. Now, the expression in Eq. (2a) for the composite elastic modulus $E_{c}$ may be cast as:

$$
\frac{2}{E_{c}}=\frac{1-v_{1}^{2}}{E_{1}}+\frac{1-v_{2}^{2}}{E_{2}}
$$

Thus Eq. (24) reveals the nature of $E_{c}$ as being the harmonic mean of the plane strain moduli of the materials in Hertzian contact. From elasticity theory perspective, the parameter terms on the right of Eq. (24), clearly indicates that deformation of materials in Hertzian contact is constrained in at least one direction [43]. Consequently, plane strain deformation may be assumed in contact stress problems. The plane-strain yield strength is about 1.155 times the yield strength in uniaxial tension [34, p. 49]. Thus, a plane strain factor $k_{p}$ is appropriate in estimating pitting strength.

\subsection{Nominal Probabilistic Design Factor}

The design parameters used in the Hertz formula are average values that are associated with $50 \%$ reliability. However, higher reliability levels are usually required in practical situations; therefore, some probabilistic considerations cannot be avoided. Osakue and Anetor [44] formulated a lognormal reliability-based design factor model that considers design parameters as random variables and characterized them with mean values and coefficients of variation (cov). The cov of each design parameter is estimated using sensitivity analysis of the first order Taylor's series expansion. The absolute values of design parameters are not required in the reliability model which is surprisingly simple because it is a function of only two parameters: the reliability parameter $(z)$ and the variability parameter $s_{m}$. The reliability parameter is the unit (standard) normal variate and defines the level of risk acceptable in a design task. The variability parameter is the lognormal standard deviation of the assumed lognormal probability density function. It combines all the significant variability in the design capacity model into one value. The reliability and variability parameters define the reliability factor for a specific design. The lognormal model [44] has been applied in the re-design of different types of components and comparison with previous results showed very good to excellent agreement. These include the design of a tension bar and crane girder [45], design of a bolt and flange joint [46], design of a cyclically loaded cantilever [47], and design of shafts for bending and torsion [48]. Appendix A briefly treats variability of contact stress design parameters and provides estimates for critical ones.

In the lognormal reliability-based design factor model [44], the lognormal standard deviation of a design capacity model is expressed as:

$$
s_{m}=\sqrt{\ln \left[\left(1+\vartheta_{C}^{2}\right)\left(1+\vartheta_{M}^{2}\right)\right]}
$$

From the variability analysis in Appendix A, $\vartheta_{C}=0.10$ and $\vartheta_{M}=0.1322$ for wrought steel products. Substituting values in Eq. (25), then:

$$
s_{m}=\sqrt{\ln \left[\left(1+0.10^{2}\right)\left(1+0.1322^{2}\right)\right]}=0.167
$$

The probabilistic design factor, which is also called reliability factor, is obtained as [44]:

$$
n_{z}=\exp \left[s_{m}\left(z+0.5 s_{m}\right)\right]
$$

The unit normal variate defines a reliability level. ASTM specifies minimum strength at a reliability of $99 \%$ and the corresponding unit normal variate is $z=2.326$. Therefore, the associated design factor in this study for wrought steel products at a reliability of $99 \%$ is:

$$
n_{o}=\exp [0.167(2.326+0.5 \times 0.167)]=1.504
$$

\subsection{Mean Strength Factor}

In probabilistic considerations, minimum and maximum values of design parameters are replaced with mean or average values [41]. However, most stress capability data available are given as minimum values. The ASTM 
minimum strength recommendation sets the value at $99^{\text {th }}$ percentile. The mean value of tensile, fatigue or any other mechanical strength can be estimated if the minimum value and cov are known. The lognormal standard deviation of the nominal strength is obtained as:

$$
s_{o}=\sqrt{\ln \left[\left(1+\vartheta_{C}^{2}\right)\right]}
$$

From the above, $\vartheta_{C}=0.10$. Substituting in Eq. (28):

$$
s_{O}=\sqrt{\ln \left[\left(1+0.1^{2}\right)\right]} \approx 0.10
$$

The minimum strength factor is obtained as:

$$
k_{o}=\exp \left[s_{o}\left(z_{o}+0.5 s_{o}\right)\right]
$$

The associated minimum strength factor in this study is:

$$
k_{o}=\exp [0.10(2.326+0.5 \times 0.10)]=1.268
$$

According to Hess et al. [49], the mean yield strength of ordinary structural steel is about 1.3 times the minimum. Therefore, the estimate above seems reasonable. It should be noted that the mean strength factor is not necessary if strength values are available in average terms. Hence, if the data available are in mean values, then the mean strength factor reduces to unity.

The Poisson's ratio of steel materials is in the range 0.27 to 0.32 with a median value of 0.295 . The mean value will be taken as $v=0.3$ for steel materials. From the above discussions the estimates for $k_{p}=1.155$ that for $k_{s}=0.755$ and at $99 \%$ reliability, $k_{o}=1.268$ and $n_{o}$ $=1.504$. Therefore, combining Eq. (21b) and Eq. (22) and substituting values, then:

$$
S_{c}^{\prime}=1.1962 S_{y t}
$$

Eq. (29) gives estimate of the nominal pitting strength for ductile steel materials at $99 \%$ reliability and may be used when experimental data on contact strength are lacking. It is approximate for other metals with compressive and tensile yield approximately equal due to differences in the values of Poisson's ratio which is in the range $0.22 \leq v \leq 0.35$ for metals.

\subsection{Nominal Contact Strength and Surface Hardness for Steel Materials}

The tensile yield strength for steel materials may be related to the tensile or ultimate tensile strength as in Eq. (30a) and Eq. (30b) becomes an alternative to Eq. (30).

$$
S_{y t}=\alpha_{y} S_{u t} \quad S_{c}^{\prime}=1.1962 \alpha_{y} S_{u t}
$$

One of the best ways to control the final condition of heat-treated gears is to specify the hardness of the tooth $[12, \mathrm{p} .4 .13]$. The tensile strength is obtained through a hardness ratio which has to be determined experimentally. When sufficient experimental data is available, the tensile strength may be expressed as in Eq. (32a) and Eq. (32b) replaces Eq. (31b).

$$
S_{u t}=\alpha_{H} H \quad S_{c}^{\prime}=1.1962 \alpha_{y} \alpha_{H} H
$$

According to Norton [2, p. 449], the yield strength of materials varies between 0.5 and 0.9 of the ultimate tensile strength. This range appears too broad for specific applications, so a compilation of tensile yield strength, ultimate tensile and hardness was done for some wrought and cast steel materials. Table A1 in Appendix A shows the results of the compilation and some other statistical data. From Table A1, the yield strength factor $\alpha_{y}$ is found to 0.6531 for normalized wrought steel and 0.8551 for quenched and tempered wrought steel. From Table A1 in Appendix A also, the hardness factor $\alpha_{H}$ is found to 3.262 for normalized wrought steel and 3.171 for quenched and tempered wrought steel. The average value for cast and wrought steel materials in Table A1 is 3.266 , which is practically the same as 3.269 , a value that is obtained when the ultimate tensile strength of steel is taken as one-third of the hardness in HVN [50, p. 127].

When the values of $\alpha_{y}=0.6531$ and $\alpha_{H}=3.2624$ for normalized wrought steels are substituted in Eq. (32b), then:

$$
S_{c}^{\prime}=2.5487 H_{s}
$$

When the values of $\alpha_{y}=0.8559$ and $\alpha_{H}=3.1711$ for quenched-tempered wrought steels are substituted in Eq. (32b), then:

$$
S_{c}^{\prime}=3.2467 H_{s}
$$

\section{ESTIMATES OF PITTING STRENGTHS}

Gears are perhaps the most common machine components where contact stresses have been and are still an area of intense study. Pitting strength data have been determined by AGMA for gear materials, especially steel materials which are commonly heat treated for improved pitting performance by two methods of through-hardening and case-hardening. Through-hardened parts have the same surface and core hardness approximately, but case-hardened parts have higher surface hardness than core hardness. Through-hardening include normalizing and quench-tempering and normalized parts can have hardness in the range of $150-320$ HVN for plain carbon steels and higher values are obtained for alloy steels. Quenched-tempering can yield surface hardness in the range of 320 to 500 HVN. Casehardening techniques are used generally when surface hardness above $425 \mathrm{HVN}$ is desired [14] and they provide surface hardness in the range of 450 to 1075 HVN with core hardness substantially lower. The commercially acceptable tolerance range for surface hardness is about 30 to $50 \mathrm{HVN}$, with $40 \mathrm{HVN}$ being common [51].

AGMA specifies grade 1, grade 2, and grade 3 quality levels for steel gear materials. Grade 2 and grade 3 materials have higher pitting strengths than grade 1 . The AGMA empirical expression for the pitting strength of through-hardened steel gear materials of grade 1 quality in the hardness range of 190 to $425 \mathrm{HVN}$, is [11, p. 800]: 


$$
S_{c}^{\prime}=2.23 H_{s}+163
$$

Table 2 shows estimates of nominal contact strengths for normalized and quenched-tempered steel materials. Column 1 of Table 2 gives the hardness values, and column 2 gives the AGMA estimates from Eq. (35). The entries in column 3 are estimates from Eq. (33) for normalized steel for 150 to $300 \mathrm{HVN}$ and Eq. (34) for quenched-tempered steel for 301 - $500 \mathrm{HVN}$. Column 4 in the table gives the percentage variance between the values in column 2 and column 3 .

Table 2: Nominal Pitting Strength Initial Estimate Comparison for Through-hardened Steel Materials

\begin{tabular}{|c|c|c|c|}
\hline \multirow{2}{*}{$\begin{array}{c}\text { Surface } \\
\text { Hardness } \\
\text { (HVN) }\end{array}$} & \multicolumn{2}{|c|}{$\begin{array}{c}\text { Nominal Pitting Strength } \\
\text { (MPa) }\end{array}$} & \multirow{2}{*}{$\begin{array}{c}\text { Variance } \\
\quad(\%)\end{array}$} \\
\hline & AGMA & $\begin{array}{c}\text { Eq. (33) or } \\
\text { (34) }\end{array}$ & \\
\hline 150 & 498 & 382 & -23.23 \\
\hline 200 & 609 & 510 & -16.30 \\
\hline 300 & 832 & 765 & -8.10 \\
\hline 400 & 1055 & 1299 & 23.10 \\
\hline 500 & 1278 & 1623 & 27.02 \\
\hline
\end{tabular}

By inspection of the variances in column 4 of Table 2, it is obvious that the estimates from Eqs. (33) and (34) are lower than AGMA values at low hardness range and higher at high hardness range. Therefore, it seems reasonable to seek adjustment of the expressions.

AGMA recommends the same value of pitting strength for steels with at most $190 \mathrm{HVN}$, indicating a possible minimum value for the pitting strength of steel materials. Hardness of annealed steels hardly exceeds $200 \mathrm{HVN}$, therefore, they may be excluded from further consideration. Hot-rolled steels can have hardness well above $190 \mathrm{HVN}$, depending on the carbon content [11]. They have comparable hardness with normalized steels. Similarly, cold-drawn steels have comparable hardness with quenched-tempered steels.

From Table A1, the yield strength factor $\alpha_{y}$ is found to be 0.7128 and the hardness factor $\alpha_{H}$ is found to 3.260 for wrought steels when annealed steels are excluded. When these values are substituted in Eq. (32b), then:

$$
S_{c}^{\prime}=2.815 H_{S}
$$

The pitting strength estimates shown in column 3 of Table 3 are generated from the expression of Eq. (36).

Table 3: Nominal Pitting Strength Final Estimate Comparison for Through-hardened Steel Materials

\begin{tabular}{|c|c|c|c|}
\hline \multirow{2}{*}{$\begin{array}{c}\text { Surface } \\
\text { Hardness } \\
\text { (HVN) }\end{array}$} & $\begin{array}{c}\text { Nominal Pitting Strength } \\
\text { (MPa) }\end{array}$ & \multirow{2}{*}{$\begin{array}{c}\text { Variance } \\
(\%)\end{array}$} \\
\cline { 2 - 3 } & AGMA & Eq. (35) & \\
\hline 150 & 498 & 422 & -15.21 \\
\hline 200 & 609 & 563 & -7.55 \\
\hline 300 & 832 & 845 & 1.50 \\
\hline 400 & 1055 & 1126 & 6.73 \\
\hline 500 & 1278 & 1408 & 10.13 \\
\hline
\end{tabular}

Tables 2 and 3 consider through-hardened wrought steels. Based on the favorable results in Table 3 , the need to investigate case-hardened steels was considered. Table 4, gives the summary of this consideration. The contact strength values of column 3 in Table 4 are from [16, p. 298]. The estimated values shown in column 4 of the table are based on Eq. (35).

Table 4: Nominal Pitting Strength Estimate Comparison for

\begin{tabular}{|c|c|c|c|c|}
\hline \multirow{2}{*}{ Material } & \multirow{2}{*}{$\begin{array}{c}\text { Surface } \\
\text { Hardness } \\
\text { (HVN) }\end{array}$} & \multicolumn{2}{|c|}{$\begin{array}{c}\text { Contact Strength } \\
(\mathrm{MPa})\end{array}$} & \multirow{2}{*}{$\begin{array}{l}\text { Dev. } \\
(\%)\end{array}$} \\
\hline & & [16] & Eq. (35) & \\
\hline Steel & 700 & $1725^{*}$ & 1971 & 14.23 \\
\hline C1015 & 745 & 1793 & 2097 & 16.96 \\
\hline C1020 & 745 & 1793 & 2097 & 16.96 \\
\hline C1117 & 820 & 2000 & 2308 & 15.42 \\
\hline 4320 & 710 & 1655 & 1999 & 20.76 \\
\hline 4620 & 745 & 1793 & 2097 & 16.96 \\
\hline 4820 & 720 & 1724 & 2027 & 17.56 \\
\hline 8620 & 800 & 1931 & 2252 & 16.62 \\
\hline E9310 & 745 & 1793 & 2097 & 16.96 \\
\hline \multicolumn{2}{|c|}{ *From [41] } & \multicolumn{2}{|c|}{ Average } & 16.94 \\
\hline
\end{tabular}
Case-hardened Steel Materials

\section{DISCUSSIONS}

The variances in Table 3 still show that the pitting strength estimates from Eq. (35) are lower than AGMA values at low hardness range and higher at high hardness range as in Table 2. However, the variances in Table 3 are much more reasonable compared to those of Table 2. The deviations shown in column 5 of Table 4 are not unreasonable. Therefore it may be concluded that very favorable comparisons exist between the predictions of Eq. (35) and AGMA values and the pitting strengths of some case-hardened steels shown in Table 4. Consequently, Eq. (35) is deemed acceptable for the initial estimate of the pitting strength of through-hardened and case-hardened steel materials. A single expression appears to predict the pitting strength of steel materials, irrespective of heat treatment method.

The reliability of the estimate of Eq. (35) is $99 \%$ but what about its load cycles or life? The contact strength is based on the yield strength of a material, suggesting that it should be for infinite load cycles. Since pitting is a wear type failure, the load cycles cannot be infinite. Now, the AGMA values in Table 3 are for a load cycle of $10^{7}$. Therefore, it is concluded that a load cycle of $10^{7}$ may be assumed for the expression developed.

In general, the pitting strength of materials is shown to be directly related to the compressive dynamic yield strength in Eq. (21). For most ductile materials, the compressive yield strength is approximately the same as the tensile yield strength which can be correlated with the ultimate tensile strength for some. For steels, the yield strength is related through the ultimate tensile strength to the hardness. Consequently, the pitting strength of steel materials is expressed as a function of the material hardness in Eq. (31) to Eq. (35). These expressions are based on the consideration of the Hertz stress formula for line contact and when the parameters therein are treated as random variables, except Eq. (34), which is empirical. The probabilistic solution is based 
on the lognormal probability density function and is quantified in a nominal design factor which is evaluated at $99 \%$ reliability. Since common property data are specified as minimum strengths and mean strength values are required in probabilistic approaches [41], correction was made through a mean strength factor for data available as minimum values. If the data available are in mean values, then the mean strength factor reduces to unity. The formulation of the expression accounts for rolling-sliding motion through a contact strength sliding factor. The presence of sliding introduces a tensile stress component in the contact zone and leads to increases in contact stress component values as well as cause the location of the maximum shear stress below the contact surface to move upward. Consideration is also taken of the fact that Hertz contact deformation is practically a plane strain deformation since the deformed volume is usually contained. Therefore, a plane strain deformation factor is used to account for this in the formulation. The expression may be used for any steel material processed by hot-rolling, cold-drawing, quenching and tempering or case-hardening.

The generalization of pitting failure of steel materials presented in Eq. (35) should enable the design engineer or designer to perform preliminary design or initial sizing of components in contact stress conditions when actual test data are unavailable, for example, if the steel material is newly developed. Usually in initial design, estimate of fatigue behavior must be made based on loading, geometry and material with limited property data available. Experiments for obtaining pitting strength data take long times and are expensive which can result in product design and development delays. However, the tensile test that provides tensile yield strength or the compressive test that provides the compressive yield strength is fast and much cheaper. For steels, the hardness test is very quick. An advantage of the strength test over the hardness test is that the strength test also provides the elastic modulus data and the compressive strength test should be preferred for pitting strength data. Therefore, compressive strength tests may be used to obtain compressive strength data that can be used in preliminary design phase for new materials. However, design verification and validation should be conducted according to standards and codes, especially those agreed on with client(s). Then prototypes of preliminary design can be built and fatigue-tested to ascertain load capability and durability. The test results should provide basis for the refinement of the preliminary design which should lead to production design models that meet desired performance targets.

Presently, correlations of hardness to pitting strength of steel materials are empirical [11, 14]. This means experiments have to done first before reasonable estimate of contact strengths can be made. Now, it has been demonstrated in this study that the pitting strength of steel materials can be correlated with the compressive dynamic yield strength. Ideally, the compressive proportional limit stress or proof strength should be used since Hertz stress theory assumes linear elastic materials. The approach developed can be applied to other metallic and non-metallic materials by using Eq. (21) and Eq. (22), with some modifications, if necessary.
It should be noted that two types of design factors are used in this study: the nominal design factor and the apparent design factor. The nominal design (Eq. (26)) is generic and applies to all types of steel materials irrespective of heat treatment method. It is based largely on the variability of design parameters. The apparent design factor (Eq. (36a)) is specific and depends on the heat treatment method of steels. It is suggested on the basis of uncertainty.

\section{DESIGN ADEQUACY AND APPARENT DESIGN FACTOR}

It is recalled that the nominal reliability design factor $\left(n_{o}\right)$ took care of the variabilities associated with stress and strength parameters. However, some design parameters are also associated with uncertainties. Uncertainty is the potential deficiency in any phase or activity of a modeling process due to lack of knowledge, though the deficiency may or may not actually occur [52]. The causes of pitting involve many environmental factors that are difficult to precisely define. An important area of knowledge deficiency is contact stress concentration data. In the assumed failure criterion in this study, a contact stress concentration factor of about 1.313 is implied but experimental data is needed. A second area of incomplete knowledge is the specific influence of residual compressive stresses from heat treatment methods on contact strength. There is evidence [53, 54, 55] of the beneficial effects of residual compressive stresses but quantification is generally lacking. Misalignment of components in assemblies and non-perfect geometries can increase loads on components during operations of machines and they are difficult to model. In the light of the above, conservative design strengths are used in gear design for instance, because the design procedures are not precise enough to account for the wide range of gear design situations and material variability and process variability do exist [34]. Hence it is reasonable to allow for unknown factors in practice that could cause premature failure [11]. This concern may be addressed by the use of an apparent design factor in assessing design adequacy. Consequently, in a design application, it is required that:

$$
n_{H}=\frac{S_{c}}{\sigma_{H}} \geq n_{c} \quad S_{c}=S_{c}^{/} Z_{c}
$$

Because most of the relevant factors are already accounted for in $n_{o}$, a modest value of $n_{c}$ should suffice. From Table 3, estimates for normalized steels are conservative, those for quenched-tempered steels are less than 15\% above AGMA values and those of case-hardened steels are less than $25 \%$ (Table 4 ) above those in the sited reference. Therefore, the following suggestions for $n_{c}$ are made:

$n_{c}=1.00 \quad$ normalized steel materials

$n_{c}=1.15 \quad$ Quenched-tempered steel materials

$n_{c}=1.25 \quad$ Case-hardened steel materials

Generally, in gearing applications, a value of 1.0 to 1.3 for $n_{c}$ is common $[56,57]$, but may be as high as 1.5 [14]. It is noted also that $n_{c}$ may be prescribed by standards or codes such as AGMA, JIS (Japanese Industrial Standard) and ISO (Internal Standardization Organi- 
zation] or may be agreed on with a client which must be adhered to. According to Petrov et al. [56], the minimum apparent design factor may be increased by $15 \%$ for critical gear drives.

In Eq. (37b), the effective pitting strength adjustment factor $Z_{c}$, is estimated when field application is desired. It can have several components, depending on the factors deemed important in a design situation. Appendix B briefly examines some pitting strength adjustment factors such as reliability factor, workhardening factor and durability or load cycles factor.

\section{CONCLUSIONS}

An expression (Eq. (36)) based on surface hardness is developed from first principles for estimating the nominal pitting strength of steel materials of different heat treatments for a reliability of $99 \%$ at $10^{7}$ load cycles. The surface hardness of steel material is measured in the Vicker's hardness scale.

Pitting strength estimates from Eq. (36) are compared with those of AGMA estimates for grade 1 steel materials and data from [16]. The formulated expression predicts lower pitting strength values at low hardness but higher values at high hardness for through-hardened (normalized and quenched-tempered) steel gears. The minimum variance for low hardness values is $-15.21 \%$ and the maximum variance for high hardness values is $10.13 \%$ for these steels. For case-hardened steels, the variances range from $14.23 \%$ to $20.76 \%$ between the estimates of Eq. (35) and available data from mainly [16]. These variances do not appear unreasonable practically and an apparent design factor can easily accommodate them as indicated in the study. Suggestions are made for estimating some pertinent adjustment factors applicable to the nominal pitting strength when considering field or service pitting strength in Appendix B.

Due to the reasonable deviations obtained from the predictions of Eq. (34), it may be stated that a more scientifically based estimation method of pitting strength has been developed for steel materials. Though the pitting strength of many commonly used steels are already determined experimentally, the expression proposed is relevant for new steel materials. More importantly, the pitting strength of other metallic and nonmetallic materials may be estimated by using Eq. (21) and Eq. (22), with some modifications, if necessary. It is because of this possibility of wider applications that this study may be considered very relevant.

\section{APPENDIX A: VARIABILITY ANALYSIS}

\section{A1.0 DESIGN PARAMETERS VARIABILITY ANALYSIS}

It is well known in practice that design loads vary randomly during equipment operations. Similarly, material properties such as yield strength, tensile strength, fatigue strength, etc. are random variables [58]. Practical design must therefore, consider the random nature and statistical variability of design parameters. Reliabilitybased design models are developed to provide practical design methods. Various tools are available for variability analysis, but the most straight forward approach appears to be the Taylor series expansion of a function. The most popular variability analysis technique in this approach is the first order Taylor series sensitivity analysis. Consider a multiplicative function of the form of Eq. (A1a). Based on Taylor series sensitivity analysis of first order, the coefficient of variation (cov) associated with Eq. (A1a) is given in Eq. (A1b) [40].

$$
z=x^{a} y^{b} \quad \vartheta_{z}=\sqrt{a^{2} \vartheta_{x}^{2}+b^{2} \vartheta_{y}^{2}}
$$

From Eq. (A1b), if $y=x$, the cov of $\mathrm{z}$ is given in $\mathrm{Eq}$. (A2a) and if $y<<x$, the cov of $z$ is given in Eq. (A2b).

$$
\vartheta_{z}=\sqrt{2} a \vartheta_{x} \quad \vartheta_{z}=a \vartheta_{x}
$$

Therefore, we expect the range of $\vartheta_{z}$ to be from $a \vartheta_{x}$ to $\sqrt{ } 2 a \vartheta_{x}$ depending on the relative size of the independent parameters when the individual cov is about the same value. The range of values of $\vartheta_{z}$ seems narrow compared to the range of relative sizes of the independent parameters. It is noted that the parameters in the expressions for the maximum contact pressure for spherical (Eq. (1a)) and cylindrical (Eq. (5a)) contacts are of this form.

Consider a summation function of the form of Eq. (A3a). Based on Taylor series of first order approximation, the cov associated with Eq. (A3a) is given in Eq. (A3b).

$$
z=x+y \quad \vartheta_{z}=\frac{1}{z} \sqrt{\vartheta_{x}^{2} x^{2}+\vartheta_{y}^{2} y^{2}}
$$

From Eq. (A3b), if $y=x$, the cov of $\mathrm{z}$ is given in Eq. Eq. (A4a) and if $y<<x$, the $\operatorname{cov}$ of $z$ is given in Eq. (A4b).

$$
\vartheta_{z}=\frac{\vartheta_{x}}{\sqrt{2}}=0.707 \vartheta_{x} \quad \vartheta_{z} \approx \vartheta_{x}
$$

Thus, the expected the range of $\vartheta_{z}$ is from 0.7079 $\vartheta_{x}$ to $\vartheta_{x}$ depending on the relative size of the independent parameters when the individual cov is about the same value. Again, the range of values of $\vartheta_{z}$ seems narrow compared to the range of relative sizes of the independent parameters. Eq. (2) can be reduced to the form of Eq. (A3a), as may be observed from Eq. (24). Now, for steel materials in Hertz contact, $E_{1}$ and $E_{2}$ are equal in values, so $\vartheta_{E c}=0.707 \vartheta_{E}$ but it is conservative to use $\vartheta_{E c}=\vartheta_{E}$. In the case of $\rho$ (Eq. (2b)), one radius of curvature can be substantially larger than the other, so $\vartheta_{\rho} \approx \vartheta_{r}$. Therefore, due to the relative narrow range of the cov value of a dependent parameter as a function of the independent parameters, generalization of worst cases can be made with some level of confidence and detail analysis of dependent complicated functions may be avoided.

Eq. (A5a) gives the expression for the plane strain or composite elastic modulus. A value of the cov of plane strain elastic modulus is obtained approximately as in Eq. (A5b) since the Poisson's ratio values for material are between 0 and 0.5 and may be considered deterministic. 


$$
E^{\prime}=\frac{E}{1-v^{2}} \quad \vartheta_{E}^{\prime}=\sqrt{\vartheta_{E}^{2}+\left(\frac{2 v^{2}}{1-v^{2}}\right)^{2} \vartheta_{v}^{2}} \approx \vartheta_{E}
$$

\section{A2.0 CONTACT STRESS VARIABILITY}

\section{A2.1 Basic capacity model variability}

Earlier, it was pointed out that pitting failure was more likely in cylindrical contact compared with spherical contact. Hence it was decided that pitting strength will be estimated based on cylindrical contact. The basic capacity model variability of Eq. (5a) or Eq. (A6a), being of the form of Eq. (A1), is given in Eq. (A6b).

$$
\begin{aligned}
& \mu_{H}=-\left[\frac{K_{s} F_{c}}{\pi b_{e}} \frac{E_{c} \times 10^{3}}{\rho}\right]^{1 / 2} \\
& \vartheta_{m H}=\sqrt{\vartheta_{k s}^{2}+\vartheta_{E c}^{2}+\vartheta_{b}^{2}+\vartheta_{\rho}^{2}+\vartheta_{m c}^{2}+\vartheta_{m c}^{2}}
\end{aligned}
$$

The parameter $K_{s}$ accounts for increases and variations in the nominal or rated load due to acceleration and deceleration of connected external and internal masses in a device, tolerances in components in an assembly and the rigidity of supporting structures. In general, it may be expressed as in Eq. (7a) and its cov obtained as in Eq. (A7b).

$$
K_{s}=K_{a} K_{i} \quad \vartheta_{k s}=\sqrt{\vartheta_{k a}^{2}+\vartheta_{k i}^{2}}
$$

Combining Eqns. (A6b) and (A7b), then:

$$
\vartheta_{m H}=\sqrt{\vartheta_{k a}^{2}+\vartheta_{k i}^{2}+\vartheta_{E c}^{2}+\vartheta_{b}^{2}+\vartheta_{\rho}^{2}+\vartheta_{m c}^{2}}
$$

The values of is in the range of 0.05 to 0.20 [58] and the values of $\vartheta_{k a}$ is in the range of 0.10 to 0.15 [59]. The possibility of both the external and internal load variations being at maximum values simultaneously is real but probably unlikely. Therefore, it is assumed that $\vartheta_{k a}=0.20$ and $\vartheta_{k i}=0.10$ in this analysis. The Young's modulus for many materials has a coefficient of variation of 3 to 5\% [60] and a value of 0.04 is taken. Variations in geometry are controlled by manufacturing practices and these are generally small, especially in mating components which is of the order of 0.001 [41] in machine design, therefore $\vartheta_{\rho}=0.001$ is taken. A cov value of 0.005 to 0.03 for length [58] may be assumed in most cases, the higher values being for smaller length sizes and $\vartheta_{b}=0.01$ is assumed. Lastly, $\vartheta_{m c}=0.05$ [59] is assumed for miscellaneous effects of approximations such as first order Taylor series. When values are substituted in Eq. (A8), then:

$$
\vartheta_{m H}=\sqrt{0.20^{2}+0.1^{2}+0.04^{2}+0.01^{2}+0.001^{2}+0.05^{2}}=0.229
$$

\section{A2.2 General miscellaneous variability}

The basic design capacity model of Eq. (5a) needs adjustments for general miscellaneous variability that accounts for analytical accuracy, failure mode correlation to mechanical capability, and human related varia- bility. This could be done by use of coefficients as suggested by [61]. That is:

$$
\mu_{M}=\sqrt{k_{m a} k_{m f} k_{m h}} \times \mu_{H}
$$

$k_{m a}$ - adjustment factor capacity model accuracy

$k_{m f}$ - adjustment factor failure model correlation with mechanical capability

$k_{m h}$ - adjustment factor human related variability

The general miscellaneous variability is obtained as:

$$
\vartheta_{m s}=\sqrt{\vartheta_{m a}^{2}+\vartheta_{m f}^{2}+\vartheta_{m h}^{2}}
$$

Engineering design models are approximations of reality and a $\operatorname{cov}\left(\vartheta_{m a}\right)$ of about $5 \%$ is reasonable in most cases [60]. The $\operatorname{cov}\left(\vartheta_{m f}\right)$ of failure mode models vary over a considerable range of 0.02 to 0.25 , the higher values being associated with fatigue failures. A cov of 0.10 appears reasonable for this analysis since contact mechanics is a complex topic. Human errors can be made during design, manufacturing, assembling, inspection, installation, operation, maintenance, and handling. A $\operatorname{cov}\left(\vartheta_{m h}\right)$ of about 7\% [60] is reasonable for complicated design tasks like gears. In summary, $\vartheta_{m a}=0.05, \vartheta_{m f}=0.10$, and $\vartheta_{m h}=0.07$ and when these values are substituted Eq. (A10):

$$
\vartheta_{m s}=\sqrt{\vartheta_{m a}^{2}+\vartheta_{m f}^{2}+\vartheta_{m h}^{2}}=\sqrt{0.05^{2}+0.1^{2}+0.07^{2}}=0.1319
$$

\section{A2.3 Effective capacity model variability}

When the basic design capacity model of Eq. (A6a) is adjusted for miscellaneous variability, then the effective variability of the design capacity model is:

$$
\vartheta_{M}=0.5 \sqrt{\vartheta_{m s}^{2}+\vartheta_{m H}^{2}}
$$

Now $\vartheta_{m H}=0.2291$ and $\vartheta_{m s}=0.135$, therefore:

$$
\begin{aligned}
& \vartheta_{M}=0.5 \sqrt{\vartheta_{m s}^{2}+\vartheta_{m H}^{2}}= \\
& =0.5 \sqrt{0.1319^{2}+0.2291^{2}}=0.1322
\end{aligned}
$$

\section{A3.0 PITTING STRENGTH VARIABILITY}

There is ample evidence of the variability of mechanical properties of materials [58]. For instance, mechanical strengths vary along bar length and among products from different suppliers. Such variations may be attributed to internal cracks and flaws, air holes in steels, cavities in welds, foreign inclusions in the materials [7] and quality of production. Blanks for making parts may be of castings, wrought (forged, extruded, rolled, drawn, stamped) materials, or of welded fabrications. From a manufacturing perspective, wrought products are generally more refined in structure than cast products and should be expected to show smaller variability in mechanical properties.

From Eqs. (19,), (21), (30), and (31) the nominal pitting strength as a function of independent parameters may be summarized in symbolic form as in Eq. (A12a) and the cov is expressed in Eq. (A12b). 
Table A1: Strength Factors and Ratios for Some Steel Materials [11, 62, 63]

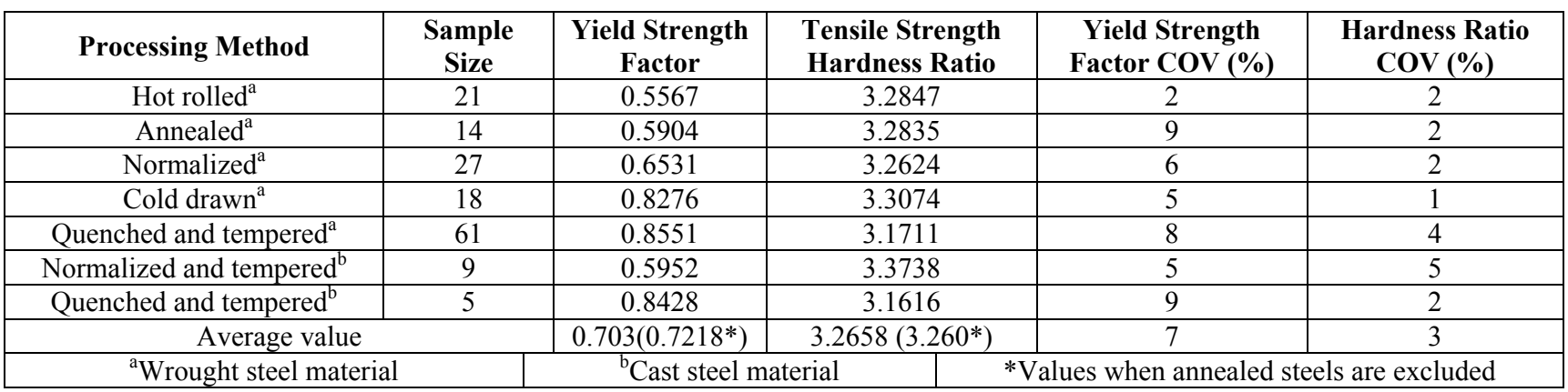

$$
\begin{aligned}
& S_{c}^{\prime}=f\left(v, \alpha_{y}, \alpha_{H}, H\right) \\
& \vartheta_{C}=\sqrt{\vartheta_{y c}^{2}+\vartheta_{\alpha H}^{2}+\vartheta_{h s}^{2}+\vartheta_{m c}^{2}}
\end{aligned}
$$

Based on Eq. (19), the expression for the $\operatorname{cov}\left(\vartheta_{y c}^{*}\right)$ of $S_{y c}^{*}$ is:

$$
\vartheta_{y c}^{*}=\sqrt{\left(\frac{1.15 v \vartheta_{v}}{1.282+1.15 v}\right)^{2}+\vartheta_{y c}^{2}} \approx \vartheta_{y c}
$$

Data on yield strength, tensile strength and hardness for steel materials with different types of processing methods such annealed, hot rolled, cold drawn, normalized, quenched and tempered were sought from [11, 62, 63]. The data for annealed, hot rolled, cold drawn, normalized, quenched and tempered were tabulated in Excel spreadsheet for mean and cov values analysis. The results of this study is presented in Table A1

From Table A1, the cov for the yield strength factor is $7 \%$ and that for the hardness ratio is $3 \%$. According to Ashby \& Jones [50, p. 127], estimating tensile strength from hardness is associated a deviation of about $\pm 10 \%$ or a cov of about $3 \%$. Poisson's ratio may be considered deterministic, but a cov of 0.02 is suggested in critical designs. In summary, for wrought steel materials, it is assumed for the current analysis that $\vartheta_{v}=0.02, \vartheta_{y c}=$ 0.07, $\vartheta_{\alpha H}=0.03, \vartheta_{h s}=0.04$, and $\vartheta_{m c}=0.05$. Substituting these values in Eq. (A14) above, then:

$$
\begin{aligned}
& \vartheta_{C}=\sqrt{0.02^{2}+0.07^{2}+0.03^{2}+0.04^{2}+0.05^{2}} \\
& =0.102 \approx 0.10
\end{aligned}
$$

Coefficient of variation for contact strength for through-hardened steel gear is 0.08 to 0.10 and that for casehardened steel gears is 0.10 to 0.12 [59, p. 162]. Therefore, the estimated value of 0.10 above is not unreasonable.

According to Ashby and Jones [50, p. 127], the ultimate tensile strength of steel in $\mathrm{MPa}$, is one-third of the hardness with a deviation of about $\pm 10 \%$. That is:

$$
S_{u t}=\frac{9.807 \mathrm{H}}{3}=3.269 \mathrm{H}
$$

$H$ is the hardness of steel material in the units of $\mathrm{kg} / \mathrm{mm}^{2}$ obtained using the Vicker's hardness scale
(HVN). From Table A1, the average value of the hardness ratio for cast and wrought steel materials is 3.266 and is practically the same as 3.269 obtained above in Eq. (A14). The variance in these two values is approximately $0.1 \%$, therefore this excellent match of the hardness ratio should inspire good confidence in the data of Table A1. The AGMA recommends the same value of pitting strength for steels with at most 190 HVN. Hot-rolled steels can have hardness well above 190 HVN, depending on the carbon content [11].

\section{APPENDIX B: SOME CONTACT STRENGTH ADJUS- TMENT FACTORS}

\section{B1.0 Service pitting strength}

The service pitting strength is that expected under service or field conditions. AGMA has extensive data on gear material properties and recommends methods for estimating service pitting strengths through the use of modification factors. Generally, the service pitting strength is obtained by applying modification factors to the nominal pitting strength [64]. The modification factors account for the influence of other factors such as load cycles different from $10^{7}$, reliability different from $99 \%$, load variability, etc. The service pitting strength may be estimated as:

$$
S_{c}=S_{c}^{\prime} Z_{c} \quad Z_{c}=Z_{n} Z_{r} Z_{w}
$$

\section{B2.0 WORKHARDENING FACTOR}

Low surface hardness gears experience some workhardening when run against harder pinions. The workhardening results from "burnishing" which involves plastic deformation of a surface in sliding contact with another object. In gearing technology, when case-hardened pinions of at least $485 \mathrm{HVN}$ are run against through-hardened gears of $190 \mathrm{HVN}$ to $425 \mathrm{HVN}$, a workhardening occurs [11, p. 761]. If the surface hardness of the gear teeth is at least $450 \mathrm{HVN}$, no burnishing is feasible and workhardening of gear by pinion does not occur [56].

In manufacturing, burnishing is generally used to make a part smoother or polished by rubbing the part with a tool. Visually, burnishing smears the texture of a rough surface and makes it shinier. It produces fine surface finishes that may be as low as $0.025 \mu \mathrm{m}, \mathrm{R}_{\mathrm{a}}$ and can increase surface hardness by as much as 5 to 10 percent or more [66]. 
Conventionally, the pitting strength is based on the member with the lower rotational speed as the one with higher rotational speed is usually made harder. Therefore:

$$
S_{c}^{\prime}=\min \left(S_{c 1}^{\prime} ; S_{c 2}^{\prime}\right)=S_{c 2}^{\prime}
$$

The parameters $E_{c}$ and $\rho$ may be construed as those of the contact patch and not the two contacting bodies. That is, the contact patch is construed as a "third body" with its unique parameters derived from those of the two contacting bodies. By observation (Eq. (2), Eq. (24)), it is noticed that contact patch parameters seems to obey the law of harmonic mean [67]. If the pitting strength is associated with the contact patch and is also assumed to obey the same law of harmonic mean, then:

$$
S_{c 3}^{\prime}=\frac{2 S_{c 1}^{\prime} S_{c 2}^{\prime}}{S_{c 1}^{\prime}+S_{c 2}^{\prime}}=S_{c}^{\prime} Z_{w}
$$

Since $S_{c}^{\prime}=S_{c 2}^{\prime}$ from Eq. (B2), combining Eq. (35) with Eq. (B3), then:

$$
Z_{w}=\frac{2 S_{c 1}^{\prime}}{S_{c 1}^{\prime}+S_{c 2}^{\prime}}=\frac{2 H_{1}}{H_{1}+H_{2}}
$$

In gear design, the range of hardness ratio between the pinion and gear is about $H_{1}>1.0 H_{2}$ and $H_{1} \leq 1.7 H_{2}$ $[2$, p. $735 ; 11$, p. 761$]$ as no substantial additional improvement in contact strength is gained for $H_{1}>1.7 \mathrm{H}_{2}$. At high surface hardness, if pitting occurs, it rapidly grows due to brittleness caused by the hardness [56]. From Eq. (B4); if $H_{1}=H_{2}$, then:

$$
Z_{w}=\frac{2 H_{1}}{H_{1}+H_{2}}=\frac{2}{1+1}=1.00
$$

When $H_{1}=1.7 H_{2}$, then form Eq. (B4):

$$
Z_{w}=\frac{2 H_{1}}{H_{1}+H_{2}}=\frac{2 \times 1.7}{1.7+1}=1.26
$$

According to Japan Industrial Standard (JIS) [68] and taking into account that hardness values are in Vicker's scale instead of Brinnel's scale:

$$
Z_{w}=1.2-\frac{H_{2}-140}{1800} \text { for } 140 \leq H_{2} \leq 500
$$

The JIS standard suggests a maximum value of 1.20 for $Z_{w}$ when $H_{2} \leq 140$ and 1.0 when $H_{2}>500$ from Eq. (B5) and Chernilevsky [57, p. 257] appears to suggest a maximum value of 1.23 . Therefore, the estimated value range of 1 to 1.26 based on Eq. (B4) above appears reasonable compared with the JIS empirical model. However, AGMA standard recommends substantially lower values of $Z_{w}$ for which a rather rough estimate may be obtained from the square root of Eq. (B4).

\section{B3.0 Reliability factor}

The nominal pitting strength values are based on $99 \%$ reliability or a failure probability of $1 \%$. Therefore it is necessary to adjust these nominal values for other reliability values. Table B2 gives values for some other reliability levels and were estimated using the method of [44]. The difference between these reliability factor values in Table B2 and those of AGMA is that the former is based on the lognormal probability density function while the latter is based on the standard normal probability distribution function [65].

Table B2: Reliability Factor for Pitting Strength

\begin{tabular}{|c|c|c|}
\hline Reliability (\%) & Normal Variate & Reliability Factor \\
\hline 50 & 0 & 1.483 \\
\hline 60 & 0.253 & 1.422 \\
\hline 70 & 0.524 & 1.359 \\
\hline 80 & 0.742 & 1.311 \\
\hline 90 & 1.288 & 1.196 \\
\hline 95 & 1.645 & 1.127 \\
\hline 99 & 2.326 & 1.000 \\
\hline 99.5 & 2.575 & 0.965 \\
\hline 99.9 & 3.091 & 0.885 \\
\hline 99.99 & 3.719 & 0.797 \\
\hline 99.999 & 4.265 & 0.728 \\
\hline 99.9999 & 4.753 & 0.671 \\
\hline
\end{tabular}

\section{B4.0 Load cycles and durability factor}

Most objects in contact fatigue such as gear teeth experience one load cycle per revolution in operation. However, some gears such idler gears and gears in planetary gear trains make multiple contacts per revolution. This translates to more than one load cycle per revolution. The load cycles for an object in contact fatigue can be estimated as:

$$
N_{c}=60 z_{c} N H_{o}
$$

The durability (or load cycles) factor is used to adjust the nominal strength for other load cycle values. Studies by AGMA and others suggest that the surface durability factor is better defined for load cycles below $10^{7}[1,26]$ because it is substantially influenced by lubrication regime at load cycles above $10^{7}$. The best lubrication condition is hydrodynamic or elastohydrodynamic where an oil or lubricant film completely separates contacting surfaces [56]. Modified but very slightly more conservative versions of AGMA recommendations for contact fatigue durability factor expressions are presented in Table B3 since the nominal pitting strength estimates above appear to be on the optimistic side for higher hardness values.

\section{Table B3: Contact Strength Durability or Load Cycles Factor}

\begin{tabular}{|c|c|c|c|}
\hline $\begin{array}{c}\text { Heat } \\
\text { Treatment }\end{array}$ & $\begin{array}{c}\text { Load Cycle } \\
\text { Range }\end{array}$ & Expression & \\
\hline Nitrided & $10^{4} \leq N_{c} \leq 10^{7}$ & $Z_{n}=2.448 N_{c}^{-1 / 18}$ & $(\mathrm{~B} 7 \mathrm{a})$ \\
\hline $\begin{array}{c}\text { Non- } \\
\text { Nitrided }\end{array}$ & $10^{4} \leq N_{c} \leq 10^{7}$ & $Z_{n}=1.251 N_{c}^{-1 / 72}$ & $(\mathrm{~B} 7 \mathrm{~b})$ \\
\hline Any type & $N_{c}>10^{7}$ & $Z_{n}=1.817 N_{c}^{-1 / 27}$ & $(\mathrm{~B} 7 \mathrm{c})$ \\
\hline
\end{tabular}

When $L_{c}>10^{7}$ load cycles, durability factor is influenced by gear material cleanliness, ductility and fracture toughness, residual stress, lubrication regime, failure criteria, pitch velocity, and smoothness of operation [26, p. 643]. The expression provided above for this regime is about average in value. 


\section{ACKNOWLEDGEMENTS}

This study was supported with funds from the College of Science, Engineering, and Technology (COSET) Research Fund and the University Faculty Development Fund of Texas Southern University, Houston, Texas. The authors are very grateful for this support.

\section{NOMENCLATURE}

HVN - Hardness: Vicker's Number

$1,2-\quad$ subscript for bodies in contact

$\rho-\quad$ composite radius of curvature (mm)

$a-\quad$ radius or half-width of contact patch

$\sigma_{H}-$ maximum contact stress (MPa)

$K_{s}-\quad$ service load factor

$F_{c}-$ contact force $(\mathrm{N})$

$E_{c}-$ composite elastic modulus $(\mathrm{GPa})$

$E_{1}-\quad$ elastic modulus of material $1(\mathrm{GPa})$

$E_{2}-$ elastic modulus of material $2(\mathrm{GPa})$

$r_{1}-\quad$ radius of sphere $1(\mathrm{~mm})$

$r_{2}-\quad$ radius of sphere $2(\mathrm{~mm})$

$v_{1}-\quad$ Poisson's ratio of material 1

$v_{2}-\quad$ Poisson's ratio of material 2

$\sigma_{z}-\quad$ normal contact stress in z-direction

$\sigma_{y}-$ normal contact stress in y-direction

$\sigma_{x}-$ normal contact stress in x-direction

$v-\quad$ Poisson's ratio of material 1 or 2

$z-\quad$ coordinate in vertical direction inside body 1 or 2

$b_{e}-\quad$ effective width of cylinder ( $\mathrm{mm}$ )

$a-\quad$ half width of contact patch

$r_{1}-\quad$ radius of cylinder $1(\mathrm{~mm})$

$r_{2}-$ radius of cylinder $2(\mathrm{~mm})$

$\lambda_{e}-\quad$ effective width factor

$b-\quad$ nominal width of cylinder (mm)

$\sigma_{e q}-$ equivalent surface contact stress

$\tau_{H}-$ maximum shear stress

$p_{H}-$ average contact stress

$S_{y c}^{*}-\quad$ dynamic contact yield strength $(\mathrm{MPa})$

$S_{y c}-\quad$ static compressive yield strength (MPa)

$S_{c}^{\prime}-\quad$ nominal pitting strength at $99 \%$ reliability

$n_{o}-\quad$ nominal contact strength design factor at $99 \%$ reliability

$k_{o}-\quad$ minimum yield strength factor

$k_{s}-\quad$ pitting strength sliding factor

$k_{p}-\quad$ pitting strength plane strain factor $s_{m}-$ lognormal standard deviation of design capacity model

$\vartheta_{M}-\quad$ effective cov of design capacity model

$\vartheta_{C}-\quad$ effective cov of mechanical capability or strength

$n_{z}-\quad$ reliability factor at a unit normal variate

$z-\quad$ unit normal variate

$n_{o}-\quad$ nominal reliability factor

$k_{o}-\quad$ mean strength factor

$S_{u t}-\quad$ ultimate tensile strength (MPa)

$\alpha_{y}-\quad$ yield strength factor

$\alpha_{H}-\quad$ tensile strength hardness ratio

$H-\quad$ hardness in HVN $\left(\mathrm{kg} / \mathrm{mm}^{2}\right)$

$s_{o}-\quad$ lognormal standard deviation of strength parameter

$H_{s}-\quad$ surface hardness in HVN $\left(\mathrm{kg} / \mathrm{mm}^{2}\right)$

$n_{H}-$ apparent design factor

$S_{c}-\quad$ service pitting strength at $99 \%$ reliability

$n_{c}-\quad$ minimum apparent design factor

$S_{c}^{\prime}-\quad$ nominal contact strength at $99 \%$ reliability

$Z_{c}-\quad$ effective pitting strength modification factor

$z-$ dependent variable

$x-\quad$ independent variable

$y$ - independent variable

$a-\quad$ exponent of $x$

$b-\quad$ exponent of $y$

$\vartheta_{z}-\operatorname{cov}$ of $z$

$\vartheta_{x}-\operatorname{cov}$ of $x$

$\vartheta_{y}-\operatorname{cov}$ of $y$

$E^{\prime}-\quad$ plane strain elastic modulus.

$E-\quad$ tensile elastic modulus.

$\vartheta_{E}^{\prime}-\operatorname{cov}$ of $E^{\prime}$

$\vartheta_{E}-\operatorname{cov}$ of $E$

$\vartheta_{k s}-\operatorname{cov}$ of $K_{s}$

$\vartheta_{E c}-\operatorname{cov}$ of $E_{c}$

$\vartheta_{b}-\operatorname{cov}$ of $b_{e}$

$\vartheta_{\rho}-\operatorname{cov}$ of $\rho$

$\vartheta_{m c}-$ miscellaneous cov for approximations

$K_{a}-$ application (external) overload factor

$K_{i}-$ internal overload factor

$\vartheta_{k i}-\operatorname{cov}$ of $K_{i}$

$\vartheta_{m s}-\quad$ cov for general miscellaneous variabilities 
$\vartheta_{m a}-\quad$ cov for capacity model accuracy

$\vartheta_{m f}-\operatorname{cov}$ for failure model correlation with mechanical capability

$\vartheta_{m h}-\quad$ cov for human related variability

$\vartheta_{M}-\quad$ effective cov for capacity model

$\vartheta_{C}-\quad$ cov for strength or mechanical capability

$\vartheta_{y c}-\quad$ cov for compressive or tensile yield strength

$\vartheta_{\alpha H}-\operatorname{cov}$ for hardness ratio

$\vartheta_{h s}-\quad \operatorname{cov}$ for hardness

$\vartheta_{m c}-$ miscellaneous cov for parameter correlation and approximations

$\vartheta_{y c}^{*}-\quad$ cov contact yield strength

$\vartheta_{v}-\quad \operatorname{cov}$ for Poisson's ratio

$S_{c}^{*}-\quad$ theoretical pitting strength at $50 \%$ reliability (MPa)

$S_{c}^{\prime}-\quad$ nominal contact strength at $99 \%$ reliability

$S_{c}-\quad$ service pitting or contact fatigue strength at $99 \%$ reliability

$Z_{c}-\quad$ effective pitting strength modification factor

$Z_{n}-\quad$ pitting strength load cycles (durability) factor

$Z_{r}-\quad$ pitting strength reliability factor

$Z_{w}-\quad$ pitting strength workhardening factor

$S_{c}^{\prime}-\quad$ nominal pitting strength of contact pair (MPa)

$S_{c 1}^{\prime}-\quad$ nominal pitting strength of faster object (MPa)

$S_{c 2}^{\prime}-\quad$ nominal pitting strength of slower object (MPa)

$S_{c 3}^{\prime}-\quad$ pitting strength of contact patch $(\mathrm{MPa})$

$Z_{w}-\quad$ workhardening factor

$H_{1}-$ hardness of upper object (HVN)

$\mathrm{H}_{2}-$ hardness of lower object (HVN)

$N_{c}-\quad$ number of load cycles

$z_{c}=$ number of contacts per revolution

$N-\quad$ rotational speed (rpm)

$H_{o}-$ design life (hrs)

\section{REFERENCES}

[1] Schmid, S. R., Hamrock, B. J. and Jacobson, B. O. Fundamentals of Machine Elements, $3^{\text {rd }}$ ed. CRC Press, New York.

[2] Norton, R. L. (2000), Machine Design: An Integrated Approach, Prentice-Hall, Upper Saddle River, New Jersey, Chap. 7.

[3] Tu, S-T and Zhang, X-C, (2016), Fatigue Crack Initiation Mechanisms, Materials Science and Materials Engineering, Elsevier. Doi:10.1016/B97 8-0-12-803581-8.02852-6.
[4] Šraml M. and Flašker, J., (2007), Computational Approach To Contact Fatigue Damage Initiation Analysis Of Gear Teeth Flanks, Int J Adv Manuf Technol, (2007) 31:1066-1075; DOI 10.1007/s00 170-005-0296-2

[5] Polasik, S. J., Williams, J. J., and Chawla, N. (2001), Fatigue Crack Initiation and Propagation in Ferrous Powder Metallurgy Alloys, Advances in Powder Metallurgy and Particulate Materials, p. 2042-2056

[6] Stolarski, T. A., Chap. 3: Elements of Contact Mechanics, Tribology in Machine Design, Butterworth-Heinemann, Oxford, 2000

[7] Bhandari, V. B. Design of Machine Elements, $3^{\text {rd }}$ ed., McGraw-Hill Education, New Delhi, P 142

[8] Glaeser, W. A. and Shaffer, S. J., (1991), Contact Fatigue, ASM Handbook, Vol. 19: Fatigue and Fracture, p 331-336

[9] Zhao, F., Ding, X., Fan, X., Cui, R., Li Y. and Wang, T., (2018), Contact Fatigue Failure Analysis of Helical Gears with Non-Entire Tooth Meshing Tests, Metals, 8, 693; doi:10.3390/met8090693

[10] Gorla, C., Rosa, F., Conrado, E. and Albertini, H. (2014), Bending and Contact Fatigue Strength of Innovative Steel for Large Gears, Proc IMechE Part C: J Mechanical Engineering Science, Vol. 228(14) 2469-2482; agepub.co.uk/journalsPermissions.nav; DOI: $10.1177 / 0954406213519614$

[11] Budynas, R. G. \& Nissbett, J. K., (2010), Shigley’s Mechanical Engineering Design, 9th ed., McGraw Hill Education.

[12] Dudley, D. W. (2009), Handbook of Practical Gear Design, CRC Press, Boca Raton.

[13] Ashby, M. F. and Jones, D. R. H., (1986), Engineering Materials 2: An Introduction to Microstructures, Processing and Design, Pergamon Press, Oxford

[14]Mott, R. L. (2004), Machine Elements in Mechanical Design, $4^{\text {th }}$ ed. (SI Units), Pearson Prentice hall, New York.

[15]Dennis P. Townsend, Common Problems and Pitfalls in Gear Design, NASA Technical Memorandum 88858, 1986 https://ntrs.nasa.gov/archive/nasa/casi.ntrs.nasa.gov /19870007600.pdf

[16]Zahavi, E. (1992), The Finite Element Method in Machine Design, Prentice Hall, Englewood Cliffs, New Jersey.

[17] Dobrovolsky, V., Zablonsky, K., Mak, S., Radchik, A., and Erlikh, L. (1965), Machine Elements, Foreign Language Pub. House, Moscow.

[18] Osakue, E. E., (1999), A Study of Friction During Low-Velocity Impact, Ph.D. Thesis, Department of Mechanical Engineering, University of New Brunswick, Fredericton, Canada.

[19]Johnson, K. L., (1985), Contact Mechanics, Cambridge University press, Cambridge.

[20] ME EN 7960, Precision Machine Design, Contact Stresses and deformations, 
https://my.mech.utah.edu/ me7960/lectures/Topic7 -ContactStressesAndDeformations.pdf

[21] Tribology Group, Part 3: Contact Mechanics, Tribological Design Guide, $2^{\text {nd }}$ ed., Institution of Mechanical Engineers, 2014.

[22] ASM Handbook, Volume 19: Fatigue and Fracture, ASM International, 1996

[23] Osakue, E. E., Simplified Spur Gear Design, Proceedings of International Mechanical Engineering Congress and Exposition 2016 IMECE, Paper Number IMECE2016-65426, November 11-17, Phoenix Arizona, USA, 2016.

[24]Fernandes, P. J. L., and McDULING C., (1997), Surface Contact Fatigue Failures in Gears, Engineering Failure Analysis, Vol. 4, No, 2, P. 99 107.

[25] Juvinall, R. C. and Marshek, K. M., Juninall's Fundamentals of Machine Component Design, SI, Wiley, Singapore, 2017.

[26] Collins, Collins, J. A., Busby, H., Staab, G. H., (2010), Mechanical Design of Machine Elements and Machines: A Failure Prevention Perspective, 2nd ed., John Wiley and Sons, New York, p. 864

[27] Tallian, T. E. (1992), Failure Atlas for Hertz Contact Machine Elements, ASME Press.

[28] Maitra, G. M., (1994), Handbook of Gear Design, McGraw-Hill Education (India), New Delhi.

[29] Shipley, E. E., (1967), Gear Failures: How to recognize them, what causes them, and how to avoid them; https://www.xtek.com/wpcontent/uploads/2018/05/xtek-gear-failures.pdf, (Accessed September 2020).

[30] Errichello R. L. and Muller, J, How to analyze gear failures;

https://www.researchgate.net/publication/22560215 9_How_to_analyze_gear_failures, (Accessed Séptember 2020).

[31] Ishibashi et al. (1984), Akira Ishibashi, Shigeru Hoyashita, Hidehiro Yoshino, Studies on Upper Limit of Surface Durability of Phosphor Bronze, Bulletin of JSME, Vol. 27 (1984) No. 225 P 592600; http://doi.org/10.1299/jsme1958.27.592

[32] Osakue, E. E. and Anetor, L., Design Sizing of Cylindrical Worm Gearsets, FME Transactions (2020), 48, 31 - 45; doi:10.5937/fmet2001031O. 2020

[33] Popov, V. L. (2010), Contact Mechanics and Friction: Physical Principles and Applications, New York.

[34]Introduction and Perspectives, Carburizing: Microstructures and Properties, ASM International, 1999; www.asminternational.org

[35] Kastratovic, G., Vidanovic, N., Grbovic, A., and Rasuo, B., Approximate Determination of Stress Intensity Factor for Multiple Surface Cracks, FME Transactions (2018), 46, 39 - 45.

[36] Grbovic, A. M., Rasuo, B. P., Vidanovic, N. D., and Peric, M. M., Simulation of Crack Propagation in Titanium Mini Dental Implants (MDI), FME Transactions (2011), 39, 165 - 170.

[37] Petrasinovic, N., Petrasinovic, D., Rasuo, B., and Milkovic, D., Aircraft Duraluminum Wing Spar Fatigue Testing, FME Transactions (2017), 45, 531 - 536; doi:10.5937/fmet1704531P.

[38] Kalpankjian, S., and Schmid, R. S. (2018), Manufacturing Processes for Engineering Materials, $6^{\text {th }}$ ed. (SI ed.), Pearson (India),

[39] Sundararajan, G., Energy Absorbed During the Oblique Impact of Hard Balls Against Ductile Target Materials, Int'l Journal of Impact Engineering, Vol. 9, No. 3, 343 - 358, 1990,

[40] Chang, W. R. and Ling, F. F. Normal Impact Model of Rough Surfaces, Journal of Tribology, Vol. 114, $439-447,1992$.

[41] Shigley, J. E. and Mischke, C. R., Standard Handbook of Machine Design, 2nd Edition,

[42]Coefficient of Friction, Engineers Edge; https://www.engineersedge.com/coeffients_of_fricti on.htm

[43] Review of Plane Stress and Plane Strain Elasticity http://w3.uacg.bg/UACEG_site/acadstaff/userfiles/study_ bg_162_L_02_Plane_Elsticity.pdf.

[44] Osakue, E. E. and Anetor, L, A Method for Estimating a Probabilistic Design Factor, Int'1 Journal of Research in Engineering and Technology, Vol. 06, Issue 08, pp. 119 - 129, 2017.

[45] Osakue, E. E. and Anetor, L., A Lognormal Reliability Design Model, Int'1 Journal of Research in Engineering and Technology, Vol. 5, Is. 7, pp. 245 - 259, 2016.

[46]Edward E. Osakue, Lucky Anetor, Christopher Odetunde, Reliability-Based Component Design, Proceedings of ASME 2015 International Mechanical Engineering Congress \& Exposition, IMECE2015, November 13-19, 2015, Houston, Texas, USA

[47] Osakue, E. E., (2013), Probabilistic Design with Gerber Fatigue Model, Mechanical Engineering Research; Vol. 3, No. 1; 2013; ISSN 1927-0607 EISSN 1927-0615; Published by Canadian Center of Science and Education

[48] Osakue, E. E., Probabilistic Fatigue Design of Shaft for Bending and Torsion, Int'l Journal of Research in Engineering and Technology, Vol. 3, Is. $9, \quad$ p. $370-386, \quad$ DOI: 10.15623/ijret.2014.0309059, 2014

[49]Hess, P. E., Bruchman, D., Assakkat, I. A., and Ayyub, B. M. (2002), Uncertainties in Material Strength, Geometric, and Load Variables, http://www.assakkaf.com/papers/Journals

[50] Ashby, M. F. and Jones, D. R. H., (2012), Engineering Materials 1: An Introduction to Properties, Applications and Design, $4^{\text {th }}$ ed. Elsevier, New York, p. 127.

[51]Dossett, J., Make Sure Your Specified Heat Treatment is Achievable, Heat Treating Progress, March/April, 2007, p. $23-30$. 
[52]Chang, K-H, (2013), Product Performance Evaluation Using $C A D / C A E$, Academic Press, Elsevier, New York, Chap. 4.

[53] Rudnev, V., (2004), Residual stresses in induction hardening: Simply Complex, Heat Treating Progress, p. $27-28$.

[54] Roux, M., Zeng, R., Wilmes, R., and Kim, K. Y., Remediation of Lost Compressive Residual Stresses in Carburized Steel Gears, Materials Engineering, Purdue

[55] R. LeMaster, B. Boggs, J. Bunn, C. Hubbard and T. Watkins, (2009, March/April), Grinding Induced Changes in Residual Stresses of Carburized Gears, Gear Technology, p. $42-49$.

[56] Petrov, M., Chernilevsky, D., Berezovsky, Y. (1988), Machine Design, MIR, Moscow.

[57] Chernilevsky, D., A Practical Course in Machine Design, MIR, Moscow, 1990. p. 498

[58] Osakue, E. E., Lognormal Reliability-Based Component Design, Technical report, Department of Industrial Technology, Texas Southern University, Houston, Texas, U.S.A, 2015.

[59] Roshetov, D., Ivanov, A., and Fadeev, V., Reliability of Machines, MIR, Moscow, 1990.

[60] Understanding Probabilistic Design, http:/www.kx cad.net/ansys/ANSYS/ansyshelp/Hlp_G_ADVPDS 1.html

[61]Ullman, G. D, Appendix C: The Statistical Factor of Safety, The Mechanical Design Process, 2nd ed., McGraw-Hill, New York, 2009.

[62] J.R. Davis, Editor, Structure/Property Relationships in Irons and Steels, Metals Handbook Desk Edition, Second Edition, 1998, ASM International, p. 153173

[63] General Properties of Steel Castings, Steel Casting Handbook, Supplement 5, Steel Founders' Society of America, p. 9 - 10.

[64]ANSI/AGMA 2001-D04, Fundamental Rating Factors and Calculation Methods for Involute Spur and Helical Gear Teeth; http://wp.kntu.ac.ir/ asgari/AGMA\%202001-D04.pdf

[65] Childs, P. R. N., Mechanical Design Engineering Handbook, Butterworth Heinemann Elsevier, Boston, 2014.

[66] Burnishing For Improved Part Quality and Lower Costs;

http://www.productionmachining.com/articles/burni shing-for-improved-part-quality-and-lower-costs
[67] Osakue, E. E. and Anetor, L., Spur Gear Design: Some New Perspectives, Int'l Journal of Research in Engineering and Technology, Vol. 5, Is. 7, pp. $275-286,2016$.

[68]KHK, Calculations of Gear Dimensions https:// khkgears.net/new/gear_knowledge/gear_technical_r eference/calculation_gear_dimensions.html, Kohara Gear Industry Co., Ltd., Saitama-ken, 332-0022, Japan.

\section{ПРОРАЧУН ОТПОРНОСТИ НА ПИТИНГ ЧЕЛИЧНИХ МАТЕРИЈАЛА}

\section{Е.Е. Осакуе, Л. Анетор, К. Харис}

Један израз за процену номиналне отпорности на питинг челичних материјала, базиран на тврдоћи површине, развијен је коришћењем првог принципа поузданости од 99\% при циклусима оптерећења $10^{7}$. Вредности тврдоће морају да се мере Викерсовом скалом тврдоће. Израз може да се користи за сваки челични материјал добијен топлим ваљањем, хладним извлачењем, каљењем и отпуштањем или цементацијом. Формула обухвата номинални фактор дизајна са поузданошћу од $99 \%$ који се израчунава помоћу пробабилистичког модела базираног на логнормалној функцији густине вероватноће. Прорачун отпорности на питинг коришћењем наведеног израза упоређен је са прорачуном који је дало удружење АГМА и подацима из других извора наведених у табелама 3 и 4. Израз предвиђа мање вредности при мањој тврдоћи али веће вредности при већој тврдоћи. Варијанса се креће између $15,21 \%$ и $10,13 \%$ код брзог каљења. Код цементације, између прорачуна и доступних података, од $14,23 \%$ до 20,26\%. Узимајући у обзир многе факторе који утичу на отпорност на питинг наведена варијанса је прихватљива. Предност приказане формуле је у томе што прорачун отпорности на питинг нових челичних материјала може да се користи при одмеравању почетног дизајна без дуготрајног и скупог испитивања контактног замора, што је потребно за евалуацију дизајна. Развијени метод прорачуна може да се примењује и за друге материјале, метале и неметале. Предлаже се примена код израчунавања неких релевантних фактора подешавања отпорности на питинг при разматрању отпорности на питинг у условима истраживања као и радним условима. 